\title{
The New Legal Hubs: The Emergent Landscape of International Commercial Dispute Resolution
}

\author{
Matthew S. Erie* \\ Forthcoming in Virginia Journal of International Law. 59(3). \\ Not for circulation or citation.
}

\begin{abstract}
New legal hubs (NLHs) are "one stop shops" for cross-border commercial dispute resolution, in financial centers, promoted as an official policy by nondemocratic or hybrid (i.e., democratic and authoritarian) states. NLHs address the problems of the legitimacy deficit of host states and also insufficient economic growth. They do so by optimizing conflict of law rules, namely choice of forum and efficiency of procedure, attracting international parties to the hub venue. Further, they suggest a novel heuristic in the study of transnational law, particularly during a period of geo-political and ideological flux. This article is based on empirical fieldwork over a period of two years in six NLHs in four countries across "Inter-Asia," including in Hong Kong, China, Singapore, Dubai, and Kazakhstan. It analyses legal hubs at two levels: their impact on host states and interhub connections as a form of transnational ordering. This article finds that, first, legal hubs are engines of doctrinal, procedural, and technological experimentation, but they have had limited impact on the reform of the wider jurisdictions within which they are embedded. Second, through relationships of competition and complementarity, legal hubs function to enhance normative settlement. However, many of the innovations (e.g., intrahub cross-institutional mechanisms between courts and arbitration institutions and interhub soft law such as memoranda of understanding) are untested, vulnerable to state politics, or even unlawful. Consequently, NLHs demonstrate the potential and fragility of "rule of law" in nondemocratic states that promote globalization against trends in the West. The article begins with an introduction that defines NLHs, identifies their significance as jurisdictional carve-outs to otherwise weak legal systems of host states, and proposes an anthropology of legal hubs. Part I sets the analysis of NLHs against the backdrop of a partially deglobalizing Euro-American liberal legal order and a globalizing Inter-Asian one. Part II describes the methodology of "para-ethnography." Part III provides a theory of NLHs. Part IV builds on this theory to generate a continuum of NLHs. Part V assesses how NLHs and their host states affect each other, including hubs'
\end{abstract}

* J.D. University of Pennsylvania Law School, LL.M. Tsinghua University, Ph.D. Cornell University; Global Hauser Fellow, NYU Law School; Associate Professor, University of Oxford. Research for the article was funded by an SSRC Transregional Research Junior Scholar Fellowship, a British Academy Small Research Grant, and a John Fell Fund Grant. The article has benefitted from presentations at Yale Law School, Columbia Law School, NYU Law School, NUS Law Faculty, Duke University, and the 2018 Law \& Society Association annual conference. The article has further benefitted from comments by Richard Brooks, William Burke-White, Jerome Cohen, Kevin Davis, Jacques deLisle, David Goddard, Mark Feldman, Tom Ginsburg, Pasha Hsieh, Jaynath Krishnan, Craig Martin, Greg Shaffer, Thomas Streinz, David Trubek, and Frank Upham. 
positive spillover effects and host state pushback. Part VI examines the possibilities for interhub ordering.

\section{Table of Contents}

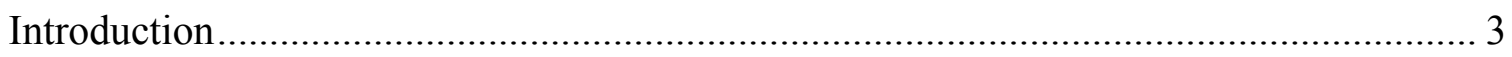

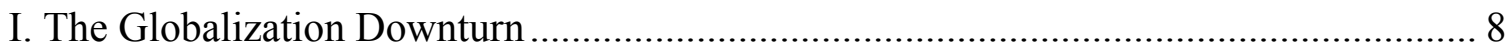

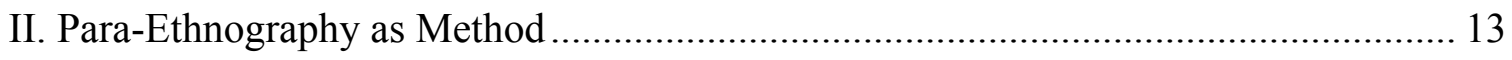

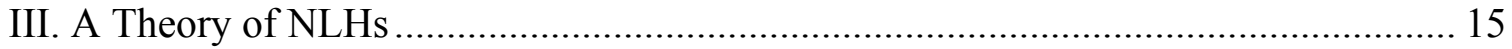

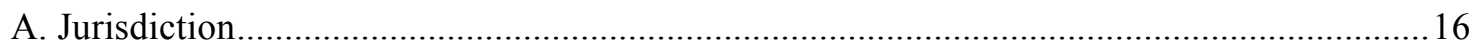

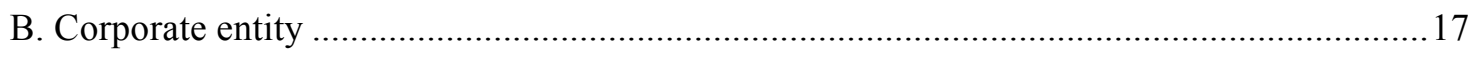

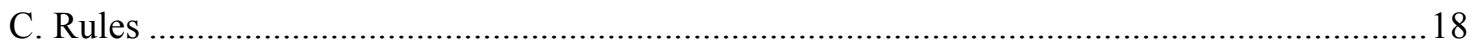

D. Dispute Resolution Mechanisms ...........................................................................19

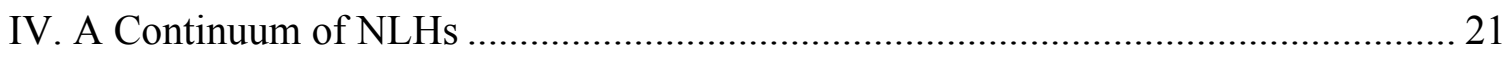

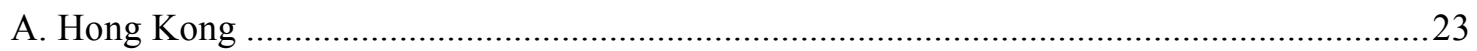

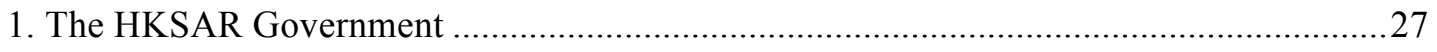

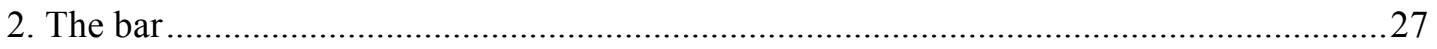

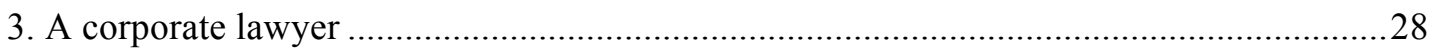

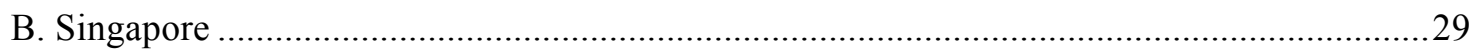

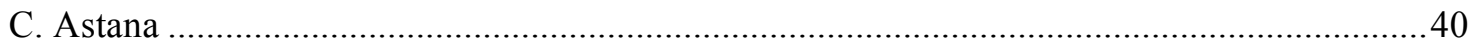

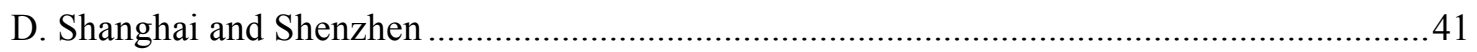

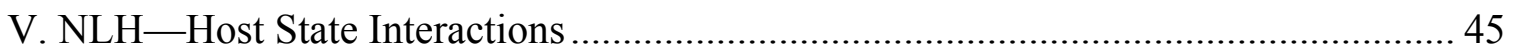

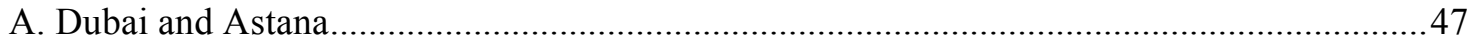

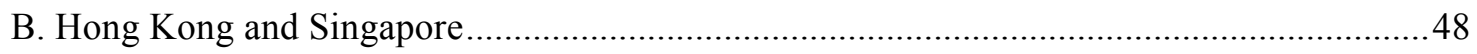

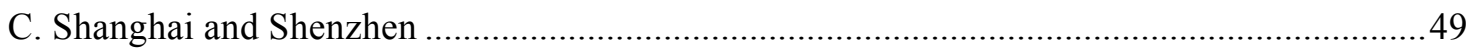

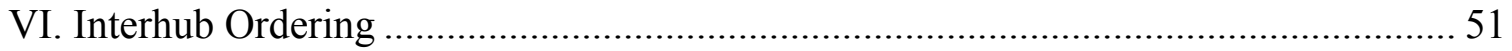

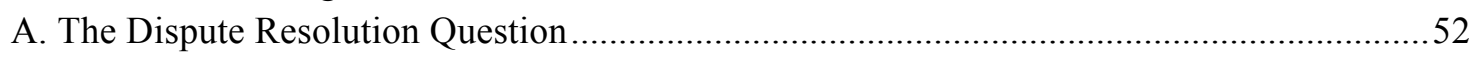

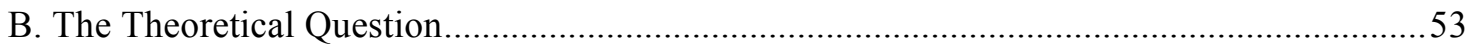

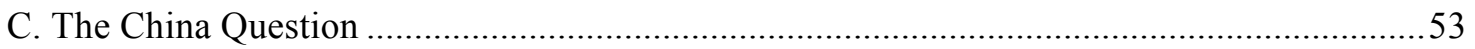

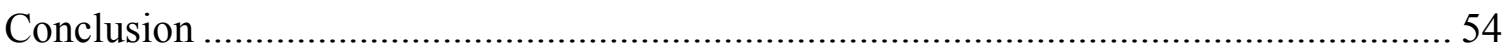




\section{Introduction}

"There are three things you need to do to make the Belt and Road Initiative [BRI] successful given all the risk," began the chief executive officer (CEO) of the Dubai International Financial Centre (DIFC) Courts to the audience of CEOs of state-owned enterprises and vice-ministerial level officials at an ultra-elite learning center for highranking members of the Chinese Communist Party in Shanghai. The speaker was addressing a key concern of many Chinese companies that are investing abroad in $\mathrm{Xi}$ Jinping's \$1 trillion effort to link China's (or the PRC's) economy with those of countries from Vanuatu to Hungary through infrastructural and energy projects, widely perceived to be the most ambitious development program in history. In answering his question, the CEO stated, "create safe harbors, become a world leader in tech, and strive for the connectivity of courts for enforcement [of foreign judgments]." Showing an image of an ocean wave crashing against a rocky outcrop to illustrate the opposing forces of economic globalization and deglobalization, the CEO spotlighted the DIFC Courts as a safe haven for the dispute resolution needs of Chinese investors operating in the Middle East.

The speaker's "safe harbors" is a synonym for a term of art that has permeated the public domain: "legal hubs." From Hong Kong and Singapore to Astana and Dubai to Shenzhen and Shanghai, "new legal hubs" (NLHs) are popping up on the landscape of cross-border commercial dispute resolution. Following post-2008 global capital flows, more cross-border deals are occurring across "Inter-Asia," an ascendant "old world" generally understood to span from the Middle East to East Asia. ${ }^{2}$ Consequently, more disputes are being resolved in Inter-Asian cities, ${ }^{3}$ some of which either already have or are building NLHs. The economic growth of China over the past forty years is central to these changing capital flows and, potentially, to the building of NLHs. The term "legal

\footnotetext{
${ }^{1}$ Personal observation, Shanghai, Mar. 10, 2018.

${ }^{2}$ Whereas the value of international commercial deals may still be greater in the United States, United Kingdom, and Western Europe, the number of deals is greater in Asia, and the value of deals may be catching up. See Tatiana Didier, et al., International Financial Integration of East Asia and Pacific, $44 \mathrm{~J}$. JAPANESE \& INT'L ECONOMIES (2017) (finding that the East Asia-Pacific region is growing faster than the North); Jones Lang Lasalle, Global Market Perspective: February 2018, JLL Global Research (2018), https:/www.jll.co.uk/en/trends-and-insights/research/jll-global-market-perspective-february-2018 (tracking volume of Asia-related transactions relative to Europe, the Americas, and the Middle East North Africa region). On the concept of "Inter-Asia," see Engseng Ho, Inter-Asian Concepts for Mobile Societies, 76 J. ASIAN STUD. 907 (2017) (understanding "Inter-Asia" as a nexus of historical and contemporary interactions - imperial, legal, and financial, among others). See also Prasenjit Duara, Asia Redux: Conceptualizing a Region for Our Times, 69 J. AsIAN STUD. 963 (2010).

${ }^{3}$ See e.g., Anselmo Reyes \& Weixia Gu, Introduction, in The DeVeloping World of Arbitration: A Comparative Study of Arbitration Reform in the Asia Pacific 1, 1 (Anselmo Reyes \& Weixia Gu eds., 2018); Queen Mary University of London and White \& Case, 2018 International Arbitration Survey: The Evolution of International Arbitration 2, https:/www.whitecase.com/sites/whitecase/files/files/download/publications/qmul-internationalarbitration-survey-2018-18.pdf (rating Shenzhen and Hong Kong as two of the world's top venues for international arbitration).

${ }^{4}$ This shift may not be so much a change as a return to a long-standing state of affairs. See ANDRE GUNDER FRANK, REORIENTING THE 19TH CENTURY: GlobAl ECONOMY IN THE CONTINUING ASIAN AgE (2015)
} 
hubs" has buzz, and percolates in the official discourse of many nondemocratic or hybrid (i.e., democratic and authoritarian) states. ${ }^{5}$ The concept is wedded to other ideas like "connectivity" and "legal harmonization" and presents a sharp contrast with U.S.

President Trump's fixation on "sovereignty." 6 This contrast is underscored by the DIFC Courts, a bespoke jurisdiction that applies English common law procedural rules in the heart of the Arabian Peninsula, promoting itself to Chinese cadre-executives in Shanghai.

This article asks: why NLHs and why now? Writing in 2005, comparative law scholar Ralf Michaels suggested, "Instead of asking how globalization has changed the role of the state in the world, we must ask how the state must change itself in order to deal with globalization." "In recent years, the question is no longer how states adapt to just economic globalization (or, "globalization"), the integration of national economies into the international economy through flows of goods, capital, services, and people since the late $1970 \mathrm{~s},{ }^{8}$ but also how they contend with what the CEO termed "deglobalization," a convergence of economic and political measures that prevent such free flows by means of trade tariffs and immigration blockades. NLHs are a product and catalyst of globalization, but they are particularly relevant in a period of globalization's slowdown. They highlight how the world order has been seemingly flipped on its head: the autocrats, monarchs, and cadres cheer the effects of globalization and the erstwhile champions of global order, namely, the United States, United Kingdom, and Western Europe are preoccupied with protecting "sovereignty."

I define a NLH as a "one-stop shop" for cross-border commercial dispute resolution, often located in financial centers, promoted as an official policy by nondemocratic or hybrid states. Taking these elements in turn, first, the idea of the onestop shop derives from late legal scholar Frank Sander's idea of the "multi-door courthouse." Sander thought that the courts of the future would provide parties with a menu of dispute resolution mechanisms, offering not just litigation but also mediation, arbitration, and ombudsmen, with an intake office to triage disputes. ${ }^{10}$ NLHs are modern day versions of the multi-door courthouse for sophisticated parties whose lawyers choose which mechanism to use. Second, NLHs overlap with other sectoral hubs: mainly financial but also infrastructural, telecom, and insurance. As centers of finance, hubs require clear rules for creating capital markets. ${ }^{11}$ Third, NLHs are located mainly in

(arguing that China was a world power until about 1850, when it was temporarily displaced by Great Britain for a century).

${ }^{5}$ See infra text accompanying notes 12-13.

${ }^{6}$ Donald Trump, Remarks by President Trump to the 73rd Session of the United Nations General Assembly, White House (Sept. 25, 2018) (using the words "sovereign" or "sovereignty" ten times), available at https://www.whitehouse.gov/briefings-statements/remarks-president-trump-73rd-sessionunited-nations-general-assembly-new-york-ny/.

${ }^{7}$ Ralf Michaels, The Re-State-ment of Non-State Law: The State, Choice of Law, and the Challenge from Global Legal Pluralism, 51 WAYNe L. REV. 1209, 1258 (2005).

${ }^{8}$ JAGDish BhagWATI, In DEFENSE OF GLOBALIZATION xi (2007).

${ }^{9}$ Frank E.A. Sander, Varieties of Dispute Processing, in THE POUND CONFERENCE: PERSPECTIVES ON JustiCE IN THE FutURE 84 (Leo A. Levin \& Russell R. Wheeler eds., 1979).

${ }^{10} I d$.

${ }^{11}$ Rumu SARKar, InTERnAtional DEVElopment Law: Rule of LAw, Human Rights, AND Global FINANCE 432 (2009) (discussing the creation of a successful regulatory framework for capital markets); Robert B. Ahdieh, Making Markets: Network Effects and the Role of Law in the Creation of Strong Securities, 76 S. CAL. L. REV. 277 (2003) (examining why law matters in the creation of securities markets in transitional states); Andrew T. Guzman, Capital Market Regulation in Developing Countries: A 
nondemocratic or hybrid states, by which I mean nonwestern states wherein power is concentrated in the hands of a few (or one) with the result that the system lacks true political pluralism, representation, and an electoral process. ${ }^{12}$ Examples of forms of government include autocracies, kleptocracies, authoritarian systems, single-party states, and hybrid regimes. ${ }^{13}$ Nondemocratic and hybrid states have different and overlapping goals, including political legitimacy (foremost in the eyes of international business parties and secondarily for domestic audiences) and economic development. Legitimacy as a legal service provider can be a precondition for economic growth. ${ }^{14}$ Depending on the relative socio-economic development of the host state, NLHs can either attract FDI or export legal services, thus serving as a multi-purpose growth strategy.

The proposition of this article is that whereas NLHs are touted as a source of globalization, because of the very design features that purportedly allow them to facilitate cross-border commercial transactions and their relative success, they may conflict with nondemocratic or hybrid host states. In other words, not despite but because of the fact that NLHs are mini-engines of globalization, they can never fully eclipse state politics. In their experiments to build credible dispute resolution institutions independent from nonliberal regimes, NLHs point to larger contradictions between "rule of law" nondemocratic governments. ${ }^{16}$ The crux of this problem derives from NLHs' underlying logic as what, following, a multi-disciplinary scholarship, including geography, development economics, anthropology, and legal history, I call, generically, "exceptional zones." ${ }^{17}$ From the state's perspective, exceptional zones are carve-outs from the

Proposal, 39 VA. J. INT’L L. 607, 609 (1998) (stating “A country that successfully establishes a regulatory regime that meets the needs of investors and issuers will encourage investment in that country").

${ }^{12}$ See, e.g., Samuel P. Huntington \& Clement H. Moore, Authoritarian Politics in Modern SOCIETY: THE DYNAMICS OF ESTABLISHED ONE-PARTY SYSTEMS (1970).

${ }^{13}$ See e.g., Daron Acemoglu, et al., Kleptocracy and Divide-and-Rule: A Model of Personal Rule, 2 J. EURO. ECON. ASSOC'N 162 (2004) (arguing that kleptocracies practice a divide-and-rule strategy, enabled by weak institutions); STEVEN LEVITSKY \& LUCAN WAy, COMPETITIVE AUTHORITARIANISM: HYBRID REGIMES AFTER THE COLD WAR (2010) (analyzing how formal democratic institutions can serve as the means of obtaining authoritarianism); Milan W. SvoliK, The Politics OF AUTHORITARIAN Rule (2012) (providing an explanation for why politics assume different forms in different types of dictatorships).

${ }^{14}$ See Richard L. ABEL \& PhiliP S.C. LEWIS, LAWYERS IN SOCIETY: AN OVERVIEW (1996) (providing a study of the role of lawyers in emergent markets). See also DAVID B. WILKINS, ET AL., THE INDIAN LEGAL Profession in the Age of Globalization: The Rise of the Corporate Legal SeCtor and Its IMPACT ON LAWYers AND SOCIETy (2017); LuCIANA Gross CunHA, ET AL., THE BRAZILIAN LEGAL PROFESSION IN THE Age of Globalization: THE Rise of THE CORPORATE LEGAL SECTOR AND ITS IMPACT ON LAWYERS AND SOCIETY (2017).

${ }^{15}$ William Hurst, Ruling Before the Law: The Politics of Legal Regimes in ChinA AND IndONESIA 22, 33 (2018) (finding hybrid regimes wherein commercial law may have effective and reliable rules and institutions (i.e., "rule of law") whereas public law is "neotraditional").

${ }^{16}$ See Nick Cheesman, Opposing the Rule of Law: How MyanmaR's Courts Make Law AND ORDER (2015); Mary E. Gallagher, Authoritarian Legality in China: LaW, Workers, and the State (2017); Tom Ginsburg \& TAmir Moustafa, Rule by LAw: The Politics of Courts in Authoritarian REgIMES (2008); Mark Fathi Massoud, International Arbitration and Judicial Politics in Authoritarian States, 39 LAW \& SOC. INQUIRY 1 (2014).

${ }^{17}$ Some of these writings are informed by critical theories of Giorgio Agamben whose "state of exception," diagnoses a situation whereby the rule-maker suspends the law allowing for naked state power. See Giorgio Agamben, State of ExCePtion 3-4 (Kevin Attell trans., 2005). See also Lorenzo Cotula, The State of Exception and the Law of the Global Economy: A Conceptual and Empirico-Legal Inquiry, 8 TRANSNAT'L LEGAL THEORY 424 (2017) (finding spatialized states of exception in global supply chains) 
applicable rules that apply to the broader jurisdiction. From a systemic perspective, exceptional zones are jurisdictional spaces where things get done-financially, militarily, educationally, and so on. Exceptional zones include tax havens, ${ }^{18}$ special economic zones (SEZs), ${ }^{19}$ free trade zones (FTZs) or free zones, ${ }^{20}$ extraterritorial jurisdictions, ${ }^{21}$ secrecy jurisdictions, ${ }^{22}$ charter cities, ${ }^{23}$ offshore jurisdictions, ${ }^{24}$ industrial parks, ${ }^{25}$ and even military bases ${ }^{26}$ and university overseas campuses. ${ }^{27}$ NLHs are another subset, and one that overlaps with other types of subsets, for example, NLHs may be established in SEZs and FTZs. The problem for exceptional zones, then, is that in creating bespoke rules and institutions that differ from those of the host state, they offer specialized goods and services to their users, but their very exceptionality can cause an array of conflicts with the host state, from institutional competition and jurisdictional turf wars to political rivalries and ideological dissonance.

NLHs, the result of unique geopolitical factors, have responded to these challenges in different ways. Given the importance of the deep context for NLHs' creation, promotion, and contestation, this article proposes an anthropology of NLHs. An anthropological approach is not limited to doctrine - as doctrine alone cannot explain how hubs work (or fail to do so). Rather, as much of the work of NLHs is symbolic in nature (e.g., branding), my approach foregrounds the conceptualizations of the proponents of NLHs, their lawyers, arbitrators, judges, and officials. Such conceptualizations are blueprints for nondemocratic states' approaches to the role of commercial law (and dispute resolution) in a period of globalization's slowdown. I juxtapose such blueprints with my own analytical understandings of NLHs, in a method

and Gerald L. Neuman, Anomalous Zones, 48 StAN. L. REV. 1197 (1996) (identifying enclaves wherein state governments suspend fundamental norms).

${ }^{18}$ Ronen Palan et al., TAX Havens: How Globalization REAlly Works (2010); NiChOlas SHAXSON, Treasure Islands: TAX Havens And the Men who Stole The World (2011); Peter J. Buckley, et al., The Economic Geography of Offshore Incorporation in Tax Havens and Offshore Financial Centres: The Case of Chinese MNEs, 15 J. ECON. GEOGRAPHY 103 (2015).

${ }^{19}$ World BANK GRP., SPECIAL ECONOMIC ZONES: AN OPERATIONAL REVIEW OF THEIR IMPACTS (2017); Douglas Zhihua Zeng, Global Experiences with Special Economic Zones: Focus on China and Africa, WORLD BANK POLICY RESEARCH WORKING PAPER NO. 7240, 2016.

${ }^{20}$ D.L.U. Jayawardena, Free Trade Zones, 17 J. World Trade L. 427 (1983); Paul Krugman, The Move Toward Free Trade Zones, Nov./Dec. 1991, at 5.

${ }^{21}$ Hannah L. Buxbaum, Territory, Territoriality, and the Resolution of Jurisdictional Conflict, 57 AM. J. CoMP. L. 631 (2009).

${ }^{22}$ Richard Murphy, Tax Havens, Secrecy Jurisdictions and the Breakdown of Corporation Tax, 57 REALWORLD ECON. REV. 56 (2011).

${ }^{23}$ Paul Romer, Why the World Needs Charter Cities, TedTalk (2009), https://www.ted.com/talks/paul romer/details (arguing that certain cities in developing countries should be governed by a charter which applies "good" foreign law).

${ }^{24}$ CHRISTOPHER BRUNER, RE-IMAGINING OFFSHORE FINANCE: MARKET-DOMINANT SMALL JURISDICTIONS In a Globalizing Financial World (2016), William J. Moon, Tax Havens as Producers of Corporate Law, 116 MiCH. L. REV. 1081 (2016).

${ }^{25}$ Frederic C. Deyo, Addressing the Development Deficit of Competition Policy: The Role of Economic Networks, in ASIAN CAPITALISM AND THE REGULATION OF COMPETITION: TOWARDS A REGULATORY Geography of Global Competition Law 293 (Michael Dowdle et al. eds., 2013).

${ }^{26}$ David Vine, Base Nation: How U.S. Military Bases Abroad Harm America and the World (2015).

27 Tom Looser, The Global University, Area Studies, and the World Citizen: Neoliberal Geography's Redistribution of the "World”, 27 CUltural ANTHROPOLOGY 97 (2012). 
of para-ethnography. This approach takes seriously how local actors design, build, and market NLHs as an exercise of "the study of how international law operates in practice, from how it is produced on a global scale to its localization on the micro-level [and vice versa]." 28

An anthropological view considers not only the different meanings attributed to NLHs and how such meanings are operationalized but, more fundamentally, the historical, geopolitical, and institutional context that gives rise to and sustains such hubs. NLHs as exceptional zones demonstrate how the designing of conflict of laws rules (i.e., jurisdiction, choice of law, and enforcement) and the practice of transnational law, the rules that apply to events and acts that cross national borders, including domestic conflict of laws, private international law, and public international law, ${ }^{29}$ may potentially attract disputes, hence capturing capital. Designs depend not only on intrahub rules but also interhub ties as well. Thus, this article adopts a two-way gaze, looking from hubs inside or into host states and looking from hubs outside or beyond states.

This article maps out the terrain of international commercial dispute resolution in emerging economies via NLHs that are nexuses for multiple transnational legal norms, for example, the diffuse norms of English common law, the more formalized norms of the UN Commission on International Trade Law (UNCITRAL), and conflict of laws norms from the Hague Conference on Private International Law, specifically, its Judgments Project, ${ }^{30}$ among other sources. My data derives from six NLHs in four countries in Inter-Asia, many of which are former colonies of the British Empire, and which continue to draw on the institutional and symbolic resources of the empire. NLHs today exist in a certain relationship to London - itself a legacy legal hub — which has been pivotal to the creation of a common law and Anglophone space for international business, influencing the NLHs examined in this article. However, as this study is focused on nondemocratic or hybrid systems, I exclude the established hubs of London, Paris, and New York. NLHs are not all necessarily "global cities," 31 but all aspire to attain such a status.

The analysis proceeds along two lines of questions: first, how do NLHs impact the host state? Specifically, do NLHs achieve their stated goals of attracting FDI or exporting legal services, and beyond that, what are the positive and negative spillover effects of building NLHs on the broader jurisdiction? The argument that NLHs have a net positive impact on the host state posits that NLHs operate as a portal or gateway for "good" law - specifically, predictable, fair, and transparent procedural rules - to enter the state. Onshore courts and other dispute resolution mechanisms can thus benefit from the presence of hubs. The argument that such hubs may have negative effects is that disproportionate resources may be allocated to NLHs, creating a drain on onshore institutions. Further, subnational jurisdictions built for elite foreign parties may foster a segregated legal system whereby local parties have no choice but to resort to suboptimal legal services.

\footnotetext{
${ }^{28}$ Galit Sarfaty, An Anthropological Approach to International Economic Law, in RESEARCH HANDBOOK ON THE SOCIOLOGY OF INTERNATIONAL LAW 296, 296 (Moshe Hirsch ed. 2018).

${ }^{29}$ Philip C. Jessup, TRANSNATiOnAL LAW 2-3 (1956).

${ }^{30}$ See Hague Conference on Private International Law Conference, Overview of the Judgments Project, available at https://assets.hcch.net/docs/905df382-c6e0-427b-a5e9-b8cfc471b575.pdf (last visited Dec. 3, 2018).

${ }^{31}$ Saskia SAssen, The Global City: New York, London, ToKyo (2d ed. 2013).
} 
The second inquiry asks what is the aggregate impact of NLHs? NLHs interact continually with each other through dynamics of both competition and collaboration in a decentralized system that supports transnational law. While there is a growing literature on "transnational legal orders" (TLOs) 32 along with other non-state forms of "global law," 33 NLHs underscore the contingency of normative orders by pointing to the distinction between design and effect. On the one hand, while NLHs are "exceptions," they may be norm-settling in terms of enforcing common rules and procedures for private disputes, and such normative settlement may occur beyond the parties to dispute and indeed between hubs; on the other hand, due to their aspirational nature, augmented by their autocratic origins, they may just as equally overreach, resulting in existing norms finding them either disorderly or even irrelevant, as a matter of legal practice. My analysis thus incorporates these two sets of questions-NLHs' impact on the host state and the broader consequences of the interhub system on international economic ordering. It does so in reference to Inter-Asia, with a particular focus on China's role in this emerging landscape of international commercial dispute resolution.

To provide an outline of subsequent parts, Part I situates the analysis of NLHs against a backdrop of a partially deglobalizing Euro-American liberal legal order and a globalizing Inter-Asian one. Part II describes my methodology. Part III provides a theory of NLHs. Part IV builds on this theory to generate a continuum of NLHs. Part V assesses how NLHs and their host states affect each other, including hubs' positive spillover effects and host state pushback. Part VI examines the possibilities for interhub ordering, and is followed by a brief conclusion.

\section{The Globalization Downturn}

The CEO of the DIFC Courts presented the idea of NLHs and their potential utility to Chinese investors, one framed as globalization versus deglobalization. At the outset, I caution against reifying the idea of deglobalization as an opposing force to globalization. Globalization has been the dominant form of interstate economic organization for over four decades whereas deglobalization has had a history of about two years, if dated to the United Kingdom European Union Membership Referendum ("Brexit") and the U.S. election, both in 2016. So while it may be premature to write of deglobalization in totalizing terms, nonetheless, NLHs do undergo pushback from various sources, including from the larger states within which they are embedded ("host states"). For the purposes of analyzing NLHs, intrastate dynamics are more important than deglobalization, although these factors may be exacerbated by incipient deglobalization.

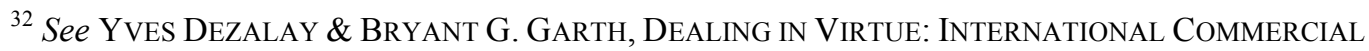
Arbitration and the CONSTRUCtion of A Transnational Legal ORder (1996); TEREnCE C. Halliday \& Gregory ShafFer, Transnational LEgal Orders (2015); Gregory C. ShafFER, TrAnSNATIONAL LEGAL ORDERING AND StATE CHANGE (2012).

${ }^{33}$ See Paul Schiff Berman, Global Legal Pluralism, 80 S. CAL. L. REV. 1155 (2007). Benedict Kingsbury, et al., The Emergence of Global Administrative Law, 68 LAw \& CONTEMP. PROBS. 15 (2005); Benedict Kingsbury \& Stephan Schill, Investor-State Arbitration as Governance: Fair and Equitable Treatment, Proportionality and the Emerging Global Administrative Law, in 50 YEARS OF THE NEW YORK CONVENTION, ICCA CONGRESS SERIES (Albert Jan van den Berg ed. 2009).
} 
While it may be too early to contrast deglobalization to globalization, the idea of such a clash warrants consideration as the problem it diagnoses has wide relevance. I use it to develop a broader theory of NLHs, albeit one that acknowledges its own limitations. To foreground the overall frame, NLHs are the result of globalization, since roughly the 1970 s to 2008 . Since 2008 , and especially following events in 2016 , they have had to contend with macroeconomic changes and state-specific challenges to their existence.

I begin with the problem, as understood: since the 1970s, and particularly since the United States changed to a policy of a floating currency, the international economic system has witnessed a lowering of trade barriers to promote free trade. There has been a concomitant growth in global governance through multilateral institutions, including the World Bank, International Monetary Fund (IMF), and United Nations (UN). In line with such institutions, a framework of rules including bilateral and multilateral treaties further supported the growth of what has been called the Washington Consensus. The Washington Consensus has pushed a package of structural reforms in developing states, including the devaluation of exchange rates to promote export-oriented industries, deregulation, reduction of tariffs and barriers to free trade, and privatization of industries. ${ }^{34}$ The reforms failed in some countries (e.g., the Soviet Union, Chile, Peru, Columbia, Ghana, and Kenya), ${ }^{35}$ yet the privatization of developing economies created new markets, mainly for multinational corporations based in the United States, Japan, the United Kingdom, and Western Europe, spurring FDI, equity investment, bond finance and debt issuance, and bank lending, the hallmarks of globalization, even if such measures resulted in greater and not lesser inequality. Following this global corporate activity and the increasingly complex nature of financial instruments, much of the literature in the 1990s identified the deterritorialization of capital as one consequence of economic globalization. ${ }^{36}$

In Inter-Asia, however, different dynamics emerged. First, in East Asia, between the 1960s and 1990s, Japan and the "tigers"-Hong Kong, Singapore, Taiwan, and South Korea - all experienced massive growth. These Asian states demonstrated divergence from the Washington Conesus in balancing the market with public administration through the central role of the state in macroeconomic policy. ${ }^{37}$ In certain cases, such as that of Singapore, the state was authoritarian, far from the prescriptions of the Washington Consensus. While a lack of risk management in commercial lending triggered the Asian financial crisis of 1997, these states enjoyed real per capita incomes that grew two to four times faster than the United States from the 1970 s to $2016 .{ }^{38}$ During this period, Japan and the Asian tigers were incorporated into international trade and investment regimes.

\footnotetext{
${ }^{34}$ IAn GOldin, DEVElopment: A Very SHORT InTROdUCTION 27 (2018).

${ }^{35}$ David M. Trubek \& Alvaro Santos, Introduction: The Third Moment in Law and Development Theory and the Emergence of a New Critical Practice, in THE NEW LAW AND ECONOMIC DEVELOPMENT: A CRITICAl APPRAISAL 6 (David M. Trubek \& Alvaro Santos eds., 2006).

${ }^{36}$ ArJun Appadurai, Modernity at LaRge: CUltural Dimensions of Globalization 38 (1996); Anthony Giddens, The Consequences Of Modernity 63 (1990); SASKia SASSEn, Losing Control? SOVEREIGNTY IN THE AGE OF GLOBALIZATION (1996); JOHN TOMLINSON, GLOBALIZATION AND CULTURE 107 (1999).

${ }^{37}$ See Robert WAde, GOVERning THE MARKET: ECONOMIC THEORY AND THE ROLE OF GOVERNMENT IN EAST ASIAN INDUSTRIALIZATION (2018).

${ }^{38}$ See Goldin supra note 34 , at 35.
} 
China is the shining example of this kind of integration into the international economic order via "selective adaptation." 39 China has adapted macroeconomic policy from industrial Western states in light of the country's size and socioeconomic circumstances. For example, based on the success of FTZs elsewhere, in 1978, China established a SEZ in Shenzhen, defined as "a specially allocated geographic area where more preferential foreign investment law and policy are implemented in order to attract foreign investment."40 Only seven years after the SEZ's founding, Shenzhen had entered into 4708 agreements with foreign investors for some $\$ 3.56$ billion. $^{41}$ The central government has replicated the Shenzhen SEZ building seven municipal-level SEZs throughout China, and these SEZs have accounted for nearly fifty percent of FDI in China. ${ }^{42}$ Much of the attraction of SEZs is their modernized legal system that provides for preferential treatment in investment, taxation, and land ownership in what are effectively exceptional zones carved-out from the host state jurisdiction. ${ }^{43}$ Hence, the logic of the exception lies at the root of China's economic growth story, and it is a logic that operates contrary to deterritorialization. The SEZ shows how exceptional zones may promote globalization through reterritorialization. In addition, China has been integrated into the global trade and investment regime through its accession to the World Trade Organization (WTO) in 2001 and its adoption of bilateral investment treaties. The argument that China's entry into the WTO would foster greater economic and political liberalization in China carried the day. Whereas the Chinese economy has become more globally integrated, the argument for political liberalization has been disproved particularly in light of Xi Jinping's leadership since 2013, a period that has seen "authoritarian resilience."

So, while on the one hand, there is adoption of and integration into the international system, on the other hand, the PRC has clearly embarked on its own path of development. This path has seen China benefit from FDI and, as of the late 1990s, begun to export capital. China's approach has taken a form of "state capitalism" whereby the state retains ownership of major industries in critical sectors. ${ }^{44}$ State control over corporations, governmental subsidies and stimulus packages, and foreign exchange reserves worth some $\$ 3$ trillion have allowed China to steer through economic shocks like the 2008 financial meltdown. ${ }^{45}$ As a result of high savings rates, China became a net capital exporter around 2015 with some $\$ 145.67$ billion in outbound direct investment,

\footnotetext{
${ }^{39}$ Pitman B. Potter, The Chinese Legal System: Globalization And Local Legal Culture (2001); Pitman B. Potter, Globalization and Economic Regulation in China: Selective Adaptation of Globalized Norms and Practices, 2 WASH. U. GLOBAL STUD. L. REV. 119 (2003).

${ }^{40}$ Henry R. Zheng, Law and Policy of China's Special Economic Zones and Coastal Cities, 8 N.Y.L. SCH. J. INT'L \& COMP. L. 193, 196 (1987).

${ }^{41} I d$., at 199.

${ }^{42}$ See World Bank Grp., supra note 19, at 18.

${ }^{43}$ See Zheng, supra note 40, at 203 (writing, "the SEZs have developed a much more comprehensive legal framework in comparison with the other areas of the PRC.")

${ }^{44}$ Benjamin L. Liebman \& Curtis J. Milhaupt, Regulating the Visible Hand? The Institutional Implications of Chinese State CAPitAlism (2016); BARry NAughton \& KelleE S. TSAi, State CApitalism, Institutional Adaptation, And the Chinese Miracle (2015).

${ }^{45}$ See Salvatore Babones, China is Sitting on \$3 Trillion in Currency Reserves, But is that Enough? FORBES (May 24, 2018), https:/www.forbes.com/sites/salvatorebabones/2018/05/24/china-is-sitting-on-3trillion-in-currency-reserves-but-is-that-enough/\#317f09065fce.
} 
placing China as the second in the world for capital outflows. ${ }^{46}$ In 2016 , China's flows reached a record high of $\$ 196.16$ billion. ${ }^{47}$ Under the BRI, China will capitalize and build infrastructure and energy projects, creating links between Beijing and low-income and middle-income countries around the globe. Xi Jinping made the role of the PRC as the defender of globalization clear at the Davos meeting in $2017 .{ }^{48}$ In short, China has adapted growth strategies, and is currently introducing these strategies to other developing states. One example of this process is the exceptional zone: in recent years, the PRC has assisted foreign states in Africa, Oceania, and Southeast Asia in developing their own SEZs. ${ }^{49}$

In addition to East Asian countries, states in the Middle East and Central Asia experienced, to varying degrees, economic growth during this period. State governments' interventionist orientation to economic development starting in the 1970s, coupled with oil revenues, saw select states leapfrog stages of capital accumulation to achieve high levels of development compared to their neighbors. ${ }^{50}$ For instance, the UAE became the leading Arab country for FDI in the early 2000s, as a result of a policy that directed investment into infrastructure and urbanization. ${ }^{51}$ Similarly, Kazakhstan has attracted more than $\$ 250$ billion in FDI since 1991, the most of any former Soviet country, with a focus on not just oil and gas but also infrastructure. ${ }^{52}$ To summarize, globalization has provided nondemocratic states with a baseline for material development, even if their development models diverge from the Washington Consensus.

So-called deglobalization has halted some of the capital flows to these states. Deglobalization is a consequence of both state action and popular "resentment" augment one another. ${ }^{54}$ Fuelling populist anger, U.S. President Trump has singled out China as the source of unfair investment and trade behavior, currency manipulation, and intellectual property theft, disadvantaging the United States. ${ }^{55}$ As a result, he has imposed

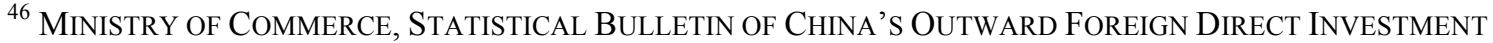
$86(2015)$.

${ }^{47}$ Ministry of COMmerce, STATistical Bulletin of ChinA's Outward Foreign Direct INVESTMent 3 (2016).

${ }^{48}$ Ceri Parker, "China's Xi Jinping Defends globalization from the Davos Stage," World Econ. F. (Jan. 17, 2017), https://www.weforum.org/agenda/2017/01/chinas-xi-jinping-defends-globalization-from-the-davosstage/ (quoting Xi: “...we should adapt to and guide globalization...”)

${ }^{49}$ See, e.g., Deborah Brautigam \& Tang Xiaoyang, "Going Global in Groups": Structural Transformation and China's Special Economic Zones Overseas, 63 WorLD Dev. 78 (2014); Hanita Cowaloosur \& Ian Taylor, Dependency and Underdevelopment: The Case of the Special Economic Zone in Mauritius, in New DiRECTIONS In AFrICA-ChINA STUdies 204 (Chris Alden \& Daniel Large eds., 2019); Cambodia Sihanoukville Special Economic Zone, Brief Introduction (Oct. 21, 2018), http://www.ssez.com/en/company.asp?Ione=3.

${ }^{50}$ Tarik M. Yousef, Development, Growth and Policy Reform in the Middle East and North Africa since 1950, 18 J. ECON. PERSPECTIVES 91 (2004).

${ }^{51}$ Anon., UAE Leads Arab Countries in FDI in 2016: Study, Gulf News: Business (Sept. 16. 2017), available at https://gulfnews.com/business/markets/uae-leads-arab-countries-in-fdi-in-2016-study1.2091080.

$\frac{1}{52}$ Anon., Economy and Business Overview, Embassy of the Republic of Kazakhstan, https://www.kazakhembus.com/Kazakhstan-economy-business (last visited Nov. 14, 2018).

${ }^{53}$ PANKAJ Mishra, Age OF ANGer: A History OF THE PRESENT (2017).

${ }^{54}$ JoSEPH E. STIGLITZ, GLOBALIZATION AND ITS DisCONTENTS REVISITED: ANTI-GLOBALIZATION IN THE ERA OF TRUMP (2018).

${ }_{55}$ Donald J. Trump, Statement by the President Regarding Trade with China, The White House (June 15, 2018), https://www.whitehouse.gov/briefings-statements/statement-president-regarding-trade-china/.
} 
tariffs on aluminum and steel imports from China (as well as Mexico, Canada, and the European Union). Much of the reaction is galvanized by a concern about a "China model" that is anathema to Western liberalism ${ }^{56}$ even if the kinds of institutions China is building (e.g., the Asian Infrastructural Investment Bank) are ones that compete with established institutions without overturning the underlying order. ${ }^{57}$

This form of deglobalization has negatively impacted cross-border business. Protectionism has resulted in a deceleration of world trade growth in 2016 and 2017, back to 2008 financial crisis rates. ${ }^{58}$ Global FDI flows fell by forty-one percent in the first half of 2018, the lowest since 2005. ${ }^{59}$ Given the hostility of the Trump administration, in 2017, China lowered its acquisitions and investments in the United States by ninety-two percent. In addition to the United States, Germany, France, Great Britain, the European Union, Australia, and other countries have blocked Chinese investments, particularly in the tech sector, stymieing Xi's "Made in China 2025" initiative. ${ }^{60}$ According to the UN Conference on Trade and Development, in 2017, Chinese outbound investment dropped for the first time since 2002 to $\$ 124.6$ billion from a peak in 2016 of $\$ 195.15$ billion. ${ }^{61}$

Contributing to the broader effects of deglobalization, law and policy in capitalexporting developed countries as well as in NLHs' host states may curb growth in exceptional zones. An example of the former is anti-money laundering and counterterrorism regulation by the United States that has resulted in de-banking in developing countries and in exceptional zones like Caribbean tax havens. ${ }^{62}$ The latter is especially

\footnotetext{
${ }^{56}$ Joshua Eisenman \& ERic Heginbotham, China StePs Out: Beijing's Major Power Engagement WITH THE DEVELOPING WORLD (2018); ZHANG WEIWEI (张维为), ZHONGGUO ZHENHAN (中国震感) [THE CHINA SHOCK] (2011); Zhu Yunhan (朱云汉) et al., Gongheguo liushinian yu Zhongguo moshi (共和国六 十年与中国模式) [People's Republic at 60 Years and the China Model], 9 DUSHU (读书) [READ BoOKS] 16 (2009); Suisheng Zhao, The China Model: Can It Replace the Western Model of Modernization, $19 \mathrm{~J}$. Contemp. China 419 (2010). But see Weitseng Chen ed. The Beijing Consensus? How China has ChANGED THE WeStERn IDEAS OF LAW AND DEVELOPMENT (2017) (arguing there is no such thing as "the China model"); Scott Kennedy, The Myth of the Beijing Consensus, 19 J. ConTEMP. China 461 (2010).

${ }^{57}$ NATALIE LiCHTENSTEIN, ASIAN INFRASTRUCTURE INVESTMENT BANK (2018).

${ }^{58}$ See Emma Richards, The Rise of Anti-Globalisation and Its Impact on Asia, ASIAN CORRESPONDENT (Jan. 20, 2017), https://asiancorrespondent.com/2017/01/rise-anti-globalisation-impact-asia/; Upfina, World Trade Growth Expected to Decline from 4.9\% to 3.7\%, Markets \& Economy (Oct. 1, 2018), https://upfina.com/world-trade-growth-expected-to-decline-from-4-9-to-3-7/ (noting how slowing growth will impact developing Asian economies' growth); World Trade Organization, Trade in 2016 to Grow at Slowest Pace Since the Financial Crisis, Trade Statistics and Outlook (Sept. 27, 2016), https://www.wto.org/english/news_e/pres16_e/pr779_e.htm.

${ }_{59}$ Tom Mills, Global FDI Falls 41 Percent in H1 2018 after Trump Tax Reforms - U.S., REUTERS (Oct. 15, 2018), https://www.reuters.com/article/us-global-economy-fdi/global-fdi-falls-41-percent-in-h1-2018-aftertrump-tax-reforms-u-n-idUSKCN1MP25B.

${ }^{60}$ Jodi Xu Klein, It's Not Just the U.S.: Around the World, Doors Are Shutting on Chinese Investment, S. CHINA MORNING POST (Sept. 13, 2018), https://www.politico.com/story/2018/09/13/china-us-investment788834

${ }^{61} I d$.

${ }^{62}$ See Rebecca L. Stanley \& Ross P. Buckley, Protecting the West, Excluding the Rest: The Impact of the AML/CTF Regime on Financial Inclusion in the Pacific and Potential Responses, 17 MELB. J. INT'L L. 83, 85 (2016) (describing how U.S. anti-money laundering and counter-terror financing measures have halted remittances to developing countries); Anon., Antigua PM Says 'No Justice' in De-Banking Caribbean Countries, Jamaica Observer (Apr. 30, 2018), available at http://www.jamaicaobserver.com/news/antiguapm-says_131865? profile $=1373$.
} 
relevant to NLHs, and I analyze examples in Part IV. To lay the groundwork for a theory of NLHs (Part III), in Part II, I discuss my methodology.

\section{Para-Ethnography as Method}

To understand the significance of NLHs for international commercial dispute resolution, I focused on the work of those who build and promote NLHs through a version of "para-ethnography." Para-ethnography (para meaning "side by side") is the description and explanation of social processes through collaborations with practitioners who are themselves engaged in quasi-social scientific "studies" of the same processes. ${ }^{63}$ Traditional ethnography, following Bronislaw Malinowski, seeks to translate meanings from one social and linguistic milieu to another, and is predicated on extended fieldwork to familiarize the anthropologist with a foreign way of thinking. ${ }^{64}$ For para-ethnography (or para-theory), however, there is no gap to close. While one consequence of this feature is a logistical one - prolonged stays "in the field" may not be necessary - another effect is epistemological. The analytical proximity between the two presents challenges for knowledge production. ${ }^{65}$

These challenges followed me in my fieldwork and generated different issues. There were, broadly, three groups with whom I interacted, and who represent the practice of transnational law in NLHs: U.K. legal specialists, transnational legal elite, and representatives of host governments. U.K. legal specialists acted as consultants to host governments that built NLHs, often serving in an official capacity as registrars of courts or secretariats to arbitration institutions. Often, retired English (or other Commonwealth) judges or solicitors are appointed as senior members of international commercial court benches or arbitration panels. My focus on U.K. legal experts and the adaptability of common law to postcolonial contexts is not to refute the possibility for civil law hubs; rather, as an empirical observation, the nondemocratic and hybrid regimes that are the focus of this study prefer the common law for hub-building. ${ }^{66}$ The transnational legal elite ${ }^{67}$ were non-U.K. nationals, sometimes from former colonies who were nonetheless trained in law in the United Kingdom, Europe, or the United States, and who took up important posts in international commercial courts and other dispute resolution venues. These multilingual, multijurisdictional talents were the keystone in the personnel structure and, as the new compradors, were the ones who "translate" between local

\footnotetext{
${ }^{63}$ Douglas R. Holmes \& George E. Marcus, Para-Ethnography, in 2 THE SAGE ENCYClOPEDIA OF Qualitative Research Methods: A-L 595 (Lisa M. Given ed., 2008); Douglas R. Holmes \& George E. Marcus, Fast Capitalism: Para-Ethnography and the Rise of the Symbolic Analyst, in FRONTIERS OF CAPitalism: Ethnographic Reflections on the NeW ECONOMY 33 (Melissa S. Fisher \& Greg Downey eds., 2006); George E. Marcus, The Uses of Complicity in the Changing Mise-En-Scène of Anthropological Fieldwork, in ETHNOGRAPHY THROUGH THICK \& ThIN 105 (George E. Marcus ed., 1998).

${ }^{64}$ Bronislaw Malinowski, Crime And Custom in SAVAGE Society (1926).

${ }^{65}$ Dominic Boyer, Thinking Through the Anthropology of Experts, 15 ANTHROPOLOGY IN ACTION 39, 3941 (2008).

${ }^{66}$ See infra note 94.

${ }^{67}$ See, e.g., Yves DeZAlay \& BRyant Garth, Asian Legal REVIVAls: LAWYERS IN the Shadow OF EMPIRE 3 (2010) (spotlighting lawyers in building legitimacy for postcolonial Asian states); Matthew S. Erie, Anticorruption as Transnational Law: The Foreign Corrupt Practices Act and Party Rules in China, AM. J. COMP. L. (Forthcoming) (focusing on the role of bicultural corporate lawyers).
} 
governmental representatives and U.K. "foreign experts." Like the U.K. experts, the transnational legal elite travel between NLHs, either assuming formal positions in different hubs at various stages in their careers, concurrently, or, alongside the U.K. specialists, visiting different hubs and conferencing with counterparts elsewhere for the purpose of sharing knowledge and addressing common problems. The third group was representatives of the host government. Over a two-year period of fieldwork, I spoke to eighty-five experts, although I identified one or two at each site who were key interlocutors.

Difficulties with the U.K. specialists and transnational legal elite fell into one bucket whereas issues with governmental officials were distinct. I shared a body of technical knowledge with the former. ${ }^{68}$ This intellectual intimacy did not create the same kind of problems experienced by other anthropologists of experts. ${ }^{69}$ Rather, it became clear that my research interests diverged from those of my interlocutors (e.g., data collection vs. business development). ${ }^{70}$ I found greater difficulty with the governmental representatives. Official discourse was saturated with the concept "legal hubs" and yet use was not consistent. The term was a "floating signifier," a label without a grounded meaning, ${ }^{71}$ locatable somewhere between "legal modernity" and "small is beautiful," and yet could be made concrete-literally so. Governmental officials were often focused on realizing the idea of a NLH by building legal infrastructure (courthouses, arbitration hearing rooms, "smart" chambers, and the like). Their discourse, then, was instrumental, part of their self-presentation as the architects of "the modern," a goal salient in emerging economies. ${ }^{72}$ Moreover, sometimes the U.K. consultants and transnational legal elite fed such fantasies, occasionally in ways that contravened the common sense of practitioners. Consequently, I tack back and forth between these "indigenous" or "emic" uses of legal hubs and my "analytical" or "etic" one. ${ }^{73}$

The bulk of data analyzed through the above methodology stems from intermittent yet intensive fieldwork in the major NLHs, visiting international commercial courts and arbitration centers, spending time with U.K. legal consultants, transnational legal elite, and government officials in formal and informal settings. I traveled to each hub, including Singapore, Hong Kong, and Shenzhen and Shanghai. Although I did not physically visit Dubai, on behalf of my academic institution, I established a memorandum of understanding (MOU) with the DIFC Courts and have participated with representatives of the DIFC Courts ${ }^{74}$ through a number of events (either at my home

\footnotetext{
${ }^{68}$ I practiced corporate law in Beijing and New York City, and have since taught law students in the United States, the United Kingdom, and China.

${ }^{69}$ See supra note 65 , at 38 .

${ }^{70}$ See also Holmes \& Marcus, Para-Ethnography, supra note 63, at 595-96.

${ }^{71}$ DANIEl ChANDLER, Semiotics: THE BASICS 78 (2007).

${ }^{72} \mathrm{Cf}$. Michael G. Peletz, Islamic Modern: Religious Courts and Cultural Politics in Malaysia (2002) (providing a study that examines the role of discourse in creating a "modern" subjectivity).

${ }^{73}$ See, e.g., Bill Maurer, Mutual Life, Limited : Islamic Banking, Alternative CuRRenCies, LATERAL REASON (2005) (suggesting a mode for ethnography that is based on lateral reasoning); ANNELISE RILES, THE NETWORK INSIDE OUT (2001) (identifying ways to defamiliarize notions of "network" through Fijian NGOs); Hirokazu Miyazaki, Economy of Dreams: Hope in Global Capitalism and Its Critiques, 21 CULTURAL ANTHROPOLOGY 147 (2006) (using Japanese derivate traders' concepts of rationality to reorient knowledge).

${ }^{74}$ See Memorandum of Understanding between the University of Oxford and the DIFC Dispute Resolution Authority, signed May 11, 2018.
} 
institution, or via conference calls and virtual meetings). Similarly, I engaged experts in Astana through telephonic and digital communication.

\section{A Theory of NLHs}

In this Part, I develop a theory of NLHs with reference to para-ethnographic views and my own definition. As part of this process, I identify the key elements of NLHs through their legal implications. Lastly, I turn to the functions of NLHs in nondemocratic and hybrid states. NLHs have a history of being overstated. While speaking with an official from the Ministry of Law of the Singapore Government, I told her I was studying legal hubs. She nodded as if she understood exactly what I meant; any explanation was unnecessary. ${ }^{75}$ Unbeknownst to me, Singapore had featured a "legal hub" discourse for at least a decade. ${ }^{76}$ Yet while there appeared to be a consensus as to the value of the term, its precise meaning was elusive. Six months earlier, a representative of the Hong Kong Department of Justice (HKDOJ) told me that the building of a legal hub was about "the creation of synergy" and then admitted, in a softer tone, that is was about "image." Economic and Trade Arbitration Commission (CIETAC) Hong Kong Arbitration Center explained that constructing a legal hub was "zaoshi," a Chinese word that he translated as "to create momentum," but that can also mean "to put a spin on something.", The Singaporean and Hong Kong renditions conveyed an element of self-conscious ambivalence. Four months before the Hong Kong conversations, I had learned of a slightly more robust idea; the CEO of the DIFC Courts explained the idea as "nodules of connectivity" or "bridgeheads" for investment into specific regions. ${ }^{79}$ His metaphors suggested a kind of spider-web geography of dispute resolution, with different regional "centers," including Dubai for the Middle East, Singapore and Hong Kong for Southeast Asia and East Asia, and Astana for Central Asia.

From this view, NLHs exist in relation to one another, as a mainly decentralized network. ${ }^{80}$ Whereas the functionality of centralized networks is determined by one hub, which determines the protocol for other hubs and, if that central hub fails, then all else fail, NLHs are, for the most part, decentralized. London has a privileged status as the metropole that has influenced NLHs by their adoption of English common law rules and English language, but the metropole no longer has a determinative effect over NLHs, even if it still has regnant symbolic capital. The idea of a single metropole is further cast into doubt given that the network responds to emergent markets. However, market orientation does not mean that hubs alter their rules for specific markets; in other words, orienting toward China does not mean sinicization (i.e., adopting PRC law and using

\footnotetext{
${ }^{75}$ Interview, Singapore, Aug. 16, 2018.

${ }^{76}$ See infra text accompany note 163.

${ }^{77}$ Interview, Hong Kong, Marc. 27, 2018.

${ }^{78} I d$.

${ }^{79}$ Interview, Oxford, Nov. 16, 2017.

${ }^{80}$ See Benjamin Peters, How Not to Network a Nation: The Uneasy History OF the SoviET INTERNET (2016); Stephan P. Borgatti et al., Network Analysis in the Social Sciences, 323 SCI. 892 (2009). See also John Friedmann \& Goetz Wolff, World City Formation: An Agenda for Research and Action, 6 INT'L J. URBAN \& REG. RESEARCH 303 (1982).
} 
Mandarin). Rather, it means promoting one's legal services for the benefit of that market. Thus, instead of a centralized system with one dominant metropole, there are multiple influential centers around which NLHs are arrayed.

Each hub has different degrees of access to and equal control over network pathways of interaction that are characterized by competition and collaboration. Competition is the result of for-profit interests in providing dispute resolution services. Activities in hubs are geared toward attracting institutional clients and persuading them to choose the legal services of the hub. International arbitration houses are the starkest example of competing interests. NLHs are constantly branding themselves as they promote their "state-of-the-art" services to institutional clients. Competition is the dynamo for innovation. Collaboration is the obverse relation. While each hub may promote its own law, they also cite one another's law in judgments. In the absence of treaties for the mutual recognition and enforcement of foreign judgments, hubs rely on soft law. In addition to soft law, hubs are connected by the networks of transnational elite that travel between them, in addition to other links such as international law offices and arbitration houses that have multiple offices in different hubs.

Legal hubs have a taken-for-granted quality in much of official discourse. In Chinese policy formation, often a "vision" precedes implementation or a pilot program, and sometimes both can take place before regulations are implemented. This approach is perhaps a feature of policy formation in autocracies generally. In Kazakhstan, for example, a member of the Astana International Financial Centre Courts (AIFC) explained to me that the President's "dream" was to build a common law court to attract international investment; once the President makes a decision, his administration then works to fulfill his interests. ${ }^{81}$ The U.K. legal specialists, in this case, Chief Justice Rt. Hon. Lord Woolf and his team, then backfill this vision, establishing the rules and mechanisms by which such a court can be established within the existing constitutional and legislative framework.

I regard these official representations as analytical windows-however rose tinted - to develop a theory of NLHs. I begin by unpacking my definition of NLHs, ${ }^{82}$ and proceed by explaining its legal implications through hubs' common features, including: jurisdiction, corporate entity, rules, and dispute resolution mechanisms.

\section{A. Jurisdiction}

Jurisdiction speaks to the fundamental question of "who decides (and according to what procedure)"? More specifically, jurisdiction refers to the ability of a hub to render a decision (court judgment, arbitral award, or mediated settlement) concerning a certain subject matter and certain persons within the bounds of a particular territory. Most hubs are "subnational" in that they are designed under and within host states. As exceptional zones, they often do not have full sovereignty under international law. ${ }^{83}$ However, NLHs have a privileged position in global markets for the reason that globalization has led to the hierarchicalization of sovereignty through the emergence of private moneys, parallel banking, and offshore special purpose vehicles. ${ }^{84}$ NLHs' subnational nature renders them

\footnotetext{
${ }^{81}$ Interview by telephone, Aug. 3, 2018.

${ }^{82}$ See supra text accompanying note 9.

${ }^{83}$ The one exception among my cases is Singapore.

${ }^{84}$ Katharina Pistor, From Territorial to Monetary Sovereignty, 18 THEORETICAL INQUIRIES IN LAW 491 (2017).
} 
smaller, bureaucratically leaner, and more nimble than states; they can respond more quickly to changes in the global political economy. One interlocutor put it bluntly: "the state is inefficient." ${ }^{\prime \prime 5}$ Subnationality, however, introduces potential problems, both normative and practical. As to the former, subnational jurisdictions can serve to legitimize a legal system that otherwise fails to provide due process, equitable results to parties, and independence from the state. In practical terms, subnationality can generate tensions with the host state in the form of jurisdictional creep. Nonetheless, as centers of financial law, they can also form ties with other hubs through soft law ${ }^{86}$ rather than interstate treaties, although they also rely on interstate treaties, such as the Convention on the Recognition and Enforcement of Foreign Arbitral Awards ("New York Convention"). ${ }^{87}$

Related to the question of jurisdiction, specifically, territorial jurisdiction, is the issue of geography. Geography is important to hubs as they abut specific regionally defined markets; the hubs' proficiency in the region's language, culture, and its having connections with government and industry are relevant factors (the "bridgeheads" metaphor). Geopolitical considerations also feed into states' decision whether to build a hub: financial motivation is not the sole criterion in states' decision making whether to build a hub; willingness to increase ties with a larger trade partner or even interstate rivalry within another state can also incentivize hub-building. Along these lines, hubs are spatially distributed; if hubs are too close, proximity can either lead to a race to the top, ${ }^{88}$ which may be a net positive, or, conversely, it could impede growth. Territorial jurisdiction is more central to some hubs over others, depending on the circumstances of their historical development and position in the decentralized system. Because of hubs' tendency to cluster legal services and dispute resolution mechanisms, physical territory becomes a premium, one that is concentrated within the host state. Geographers call this the "agglomeration effect," and such studies are replete with metered-measurements of distances between buildings (where goods or services are produced). ${ }^{89}$ These territorial concentrations vary across different scales, some can be financial centers of a half-mile squared, and others can be city-states of a thousand square miles). So while the venues of NLHs are concentrated, their territorial jurisdiction is broadened to capture as many disputes as possible, and, in particular, those involving nonlocal parties.

\section{B. Corporate entity}

NLHs are established as a corporate entity or operated by host state's governments as if they are a corporation. In line with "state capitalism" in autocratic regimes, the government plays a central role in organizing the state's economic policy

\footnotetext{
${ }^{85}$ Interview, London, Nov. 6, 2017. See also Klaus Peter Berger, The Creeping Codification of the NEW LEX MERCATORIA (2010) (arguing that domestic law and judicial doctrine are brakes on transnational commerce).

${ }^{86}$ Chris Brummer, Soft LAW AND THE Global FinANCIAL SYSTEM: Rule MAKING IN THE 21 ST CENTURY (2012).

${ }^{87}$ Convention on the Recognition and Enforcement of Foreign Arbitral Awards, signed June 10, 1958, effective June 7, 1959, available at $\mathrm{http} / / / \mathrm{www}$.uncitral.org/pdf/english/texts/arbitration/NY-conv/NewYork-Convention-E.pdf.

${ }^{88}$ Barry R. Weingast, The Economic Role of Political Institutions: Market-Preserving Federalism and Economic Development, 11 J.L., ECON., \& ORG. 1 (1995).

${ }^{89}$ See Michael StORPer, The Regional World: Territorial Development in a Global ECONOMY (1997) 54 (defining agglomeration as the additive result of individual optimizing producers).
} 
and behavior, frequently in the form of state ownership of key sectors. More specifically, the government (party-state, religious monarch, etc.) has controlling stakes in major corporations by establishing a central holding company, which also supervises corporate activity. ${ }^{90}$ The NLH may take the form of an international financial center with its own corporate body, organized under relevant state law headed by a board, which assumes liability for activities arising under the mandate of the corporation. Often, the governmental leader or its representatives will appoint the president (or equivalent) of the board. Alternatively, if a hub does not take the form of a single corporation, managerial elites in a single-party state may form an "encompassing organization" "91 that effectively owns the various constitutive parts of a hub (e.g., international arbitration institution, international commercial court, or the physical plant in which one or both are housed) even if those parts are presented as independent from the government. Corporate interests thus drive the generation of revenue by the provision of legal services. Yet state corporate ownership of hubs may introduce legitimacy problems, exacerbating perceptions by potential users of partiality, particularly in the event a dispute involves a government entity or state-owned enterprise (SOE).

\section{Rules}

As nexuses of complex trade and investment relationships, NLHs are concerned mainly with civil and commercial matters. Hence, legal service providers are focused on corporate concerns, running the gamut from energy, mining, construction, project finance, and maritime transactions to intellectual property, labor, environment, public procurement, and other regulatory matters. Dispute resolution takes the form of international arbitration, international litigation, and business mediation.

The law NLHs apply works to lift parties out of the domestic law of the host state. Legal systems in autocratic states are plagued by corruption, local protectionism, political favoritism, lack of judicial expertise, and underfunding. ${ }^{92}$ Inspired by neoliberal prescriptions for growth via urbanization and institution-building as espoused by the World Bank and the IMF, ${ }^{93}$ hubs apply good law so that users benefit from international standards. This means that hubs develop pro-business substantive and procedural law based on English common law, considered to be the lingua franca of international transactions. The transplantation of English common law to nondemocratic and hybrid states has been a reoccurring process in the comparative law of the postcolony. ${ }^{94}$ In terms

\footnotetext{
${ }^{90}$ See, e.g., Li-Wen Lin \& Curtis J. Milhaupt, We Are the (National) Champions: Understanding the Mechanisms of State Capitalism in China, 65 STAN. L. REV. 697 (2013).

${ }^{91} I d$. at 702.

${ }^{92}$ See Ginsburg \& Moustafa, supra note 16; Mark Fathi Massoud, LaW's Fragile State: Colonial, AUTHORITARIAN, AND HUMANITARIAN LEGACIES IN SUdAN (2013).

${ }^{93}$ KenNeth W. Dam, The LaW-Growth NeXus: The Rule of LaW and Economic Development (2006); World Bank, From Plan to Market: World DeVelopment Report (1996); David M. Trubek, The "Rule of Law" in Development Assistance: Past, Present, and Future, in THE New LAW AND DeVelopment: A CRitical APPRAISAl 74 (David M. Trubek \& Alvaro Santos eds., 2006). But see Jamie Peck \& Eric Shepperd, Worlds Apart? Engaging with the World Development 2009: Reshaping Economic Geography, 86 ECON. GEOGRAPHY 331(2010) (disputing whether World Bank prescriptions for institutions as growth benefit peripheral economies).

94 See Martin CHANOCK, LAw, CUSTOM AND SOCIAL ORDER: THE COLONIAL EXPERIENCE IN MALAWI AND Zambia (1985); TerenCe C. Halliday Et Al., FAtes of Political Liberalism in the British PostColony: The Politics of the Legal Complex (2012); NAsSer Hussain, The Jurisprudence of
} 
of corporate law, for example, this means the right to establish a $100 \%$-owned foreign company (e.g., a limited liability company) without nationality requirements, the absence of restrictions on foreign shareholders, the lack of foreign exchange controls, tax incentives, double tax treaties, ease of reporting requirements for foreign companies, and strong protection of intellectual property, among other advantages. Rules are continually improved upon — or tweaked around their edges — to enhance their capacity to grow business.

Parties do not need to be incorporated under the substantive laws of the NLHs as hubs specialize in settling disputes of non-local parties, even if they do not have a local corporate presence. NLHs endorse freedom of contract in terms of parties electing the substantive law, a freedom that is particularly relevant in terms of the governing law for the dispute resolution clause. Where possible, parties may opt out of the default law of the hub to choose their own law; as a consequence, NLHs are nodes of transnational law. ${ }^{95}$ This function is enhanced when, in the process of resolving disputes, experts in NLHs interpret inter-corporate agreements (e.g., loan agreements, credit facility agreements, etc.) instead of applying substantive law.

Procedural rules across hubs draw from international instruments and institutions for arbitration and English common law for the commercial courts, showing what Alec Stone Sweet and Florian Grisel have called "institutional isomorphism." 96 For international arbitration, the UNCITRAL has served as the basis for domestic arbitration law in some hubs ${ }^{97}$ and the International Chamber of Commerce (ICC) has set the agenda for reform. On the side of litigation, many commercial courts demonstrate convergence, particularly on questions of jurisdiction, venue, joinder of parties, English as working language, public proceedings, evidence, costs, third-party funding, and enforcement. ${ }^{98}$ The convergence of procedural rules shows a kind of equilibrium within the decentralized system.

\section{Dispute Resolution Mechanisms}

The core of the "one-stop shop" idea is that both at the predispute and dispute stages, a NLH provides all relevant legal services. The benefit of the concept of the "onestop shop" is that it combines both litigation and non-litigation mechanisms (i.e., arbitration and mediation), overcoming some of the "either/or" logic that has

\footnotetext{
EMERGENCY: COLONIALISM AND THE RULE OF LAW (2009); ElisABETH KOLSKY, COLONIAL JUSTICE IN BRITISH INDIA (2011); JOTHIE RAJAH, AUTHORITARIAN RULE OF LAW: LEGISLATION, DiSCOURSE AND LEGITIMACY IN SingAPORE (2012); OSAMA SidDIQUE, PAKISTAN'S EXPERIENCE WITH FORMAL LAW: AN ALIEN JUSTICE (2013).

95 See supra note 29.

96 Alec Stone SweEt \& Florian Grisel, The Evolution of InTERnAtional Arbitration 8 (2017).

${ }^{97}$ Hong Kong and Singapore, as the two most significant international arbitration seats, have adopted the UNCITRAL Model Law on International Commercial Arbitration. See Gary F. Bell, Introduction: The Model Law and its Importance in Asia, in THE UNCITRAL MODEL LAW AND ASIAN ARBITRATION LAWS: IMPLEMENTATION AND COMPARISONS 1 (Gary F. Bell ed. 2018).

${ }^{98}$ See Mahika Hart, Comparison of Procedural Rules, Mar 8, 2016, on file with the author (providing a comparison between the Rules of the DIFC Courts, the Rules of Transnational Civil Procedure, the Abu Dhabi Global Market Courts Proposed Rules and Regulations, the United Arab Emirates (UAE) Civil Procedure Code, and the Singapore International Court Procedural Rules, showing "many areas of procedural regulation remain substantively the same across diverse jurisdictions").
} 
characterized the ADR literature. ${ }^{99}$ Sander's "multi-door courthouse" ${ }^{, 100}$ was not necessarily meant for nondemocratic regimes, but it is in such postcolonial Inter-Asian contexts where the idea may find most traction. ${ }^{101}$ One consequence of hubs being jurisdictional carve-outs that apply transnational law is that by having procedural rules that can potentially be independent from the host state's legislature, NLHs are able to develop cross-institutional mechanisms that are responsive to parties' needs and market preferences. However, as I will show, some of these innovations are not practical given that they may require enforcement outside the forum.

In analyzing the foregoing elements, it becomes apparent that much of the legal work that NLHs do touches on matters of conflict of laws: jurisdiction, choice of law, and enforcement. Thus, in considering NLHs' functions, hubs develop institutions and rules that promote flexibility for international parties to choose transnational law to resolve problems. From a managerial perspective, the NLH seeks not only to generate profits, but also to maximize its own utility to the host state as stakeholder. Equal parts capital requirements, on the one hand, and intrastate and public relations, on the other hand, NLHs have both functional and symbolic purposes.

Beginning with the former, NLHs are designed to hook capital by attracting crossborder commercial disputes through a number of business models. I use London as a reference since many NLHs emulate London. First, there are the arbitration fees. According to a study conducted by the London-based Chartered Institute of Arbitrators in 2011, the average international commercial arbitration case cost 1,348,000 GBP (US\$1,773,341) in common law jurisdictions and 1,521,000 GBP (US\$2,000,928) in civil law countries. ${ }^{102}$ Arbitration houses vary in their costs, but a common complaint is that, since two-thirds of the total costs can be lawyers' fees and lawyers drive the process, arbitration has become excessively costly. Hence, a second business model in hubs is that of the law firms, including U.K. firms, U.S. firms, internationalizing Chinese firms, and local law firms, that generate revenue through billable hours in handling matters for clients either incorporated at the hub or who have elected to use that forum for their dispute resolution. Lawyer fees include not just transactional matters but also litigation, arbitration, and mediation. To give one data point, the top fifty law firms in London earned a total of 20 billion GBP (US\$26.3 billion) in $2017 .{ }^{103}$ So while proponents of

\footnotetext{
${ }^{99}$ See e.g., LAUra NADER, The Life of The LAW: Anthropological Projects (2002); Marc Galanter, “...A Settlement Judge, not a Trial Judge:” Judicial Mediation in the United States, 12 J.L. \& Soc’Y 1 (1985).

${ }^{100}$ See supra note 9.

${ }^{101}$ The idea has been floated in the U.S. in the 1980s, in Africa in the early 2000s, and more recently in Latin America. See e.g., Louise Phipps Senft \& Cynthia A. Savage, ADR in the Courts: Progress, Problems, and Possibilities, 108 PENN ST. L. REV. 327, 327 (2003); Gladys Kessler \& Linda J. Finkelstein, The Evolution of a Multi-Door Courthouse, 37 CATH. U. L. REV. (1988); Bukola Faturoti, Institutionalised ADR and Access to Justice: The Changing Faces of the Nigerian Judicial System, 1 J. COMP. L. IN AFR. 66 (2014); Marina D. Hernandez-Crespo, From Noise to Music: The Potential of the Multi-Door Courthouse (Casas de Justicia) to Advance Systemic Inclusion and Participation as a Foundation for Sustainable Rule of Law in Latin America, J. DisP. RESOL. (2012).

${ }^{102}$ Chartered Institute of Arbitrators, CIArb Costs of International Arbitration Survey 2011 p. 01 (2011), https:/www.international-arbitration-attorney.com/wp-content/uploads/2017/01/CIArb-Cost-ofInternational-Arbitration-Survey.pdf.

${ }^{103}$ See LEGAL WeEK, UK Top 50 2016-2017: The Largest Commercial Law Firms in the UK Ranked by Revenue, https://images.law.com/contrib/content/uploads/sites/378/2017/09/Top50results2017_v6_SMALL.pdf.
} 
hubs have some incentive to push the application of their own substantive law, as doing so benefits the local bar who are experts in that law, most hubs feature international law firms that are proficient in transnational law. As opposed to arbitration and lawyer fees, court fees and mediation fees are relatively insignificant. For instance, for the DIFC Courts, fees are $\$ 135,000$ for a claim over $\$ 50$ million, and upon early settlement, fees are returned to the parties. ${ }^{104}$ Business mediation centers charge similar nominal numbers. In addition to the core mechanisms for dispute resolution, there are also auxiliary services, such as law clerks, paralegals, notaries, and instructors at legal academies who are affiliated with hubs. In total, the revenues generated by the legal industry and its dispute resolution services can be a substantial means of capturing capital for the host state.

Complementing the role of hubs as revenue generators, they are also producers of what scholars of management studies call "image-work," the creation of narratives that are self-legitimating. ${ }^{105}$ Specifically, hubs engage in image-work for multiple audiences including the host state, and more importantly for my purposes, the world beyond the host state. The former legitimizes their expenses to the host state and the latter signals positive public relations on behalf of host states. The image-work function, while less easily reducible to numbers, is no less prominent in the minds of NLH exponents, particularly given that most nondemocratic states run a public relations debt. An observation made by the sociology of international arbitration is that, given that arbitrators are often chosen based on reputation, the industry subsists on prestige. ${ }^{106}$ NLHs have adopted this value, sometimes ostentatiously. It is most clearly reflected in borrowing the symbolism of the British empire, hypermodern legal infrastructure, and futuristic "lawtech" (including artificial intelligence (AI), big data, and machine learning). All of these features are meant to present the NLH as a safe place for commercial disputes. Like a thin rock skipped on the water's surface, NLHs are where global capital touches down. With this understanding of NLHs, in the next part, I provide a spectrum of NLHs to further delineate them from nonhubs.

\section{A Continuum of NLHs}

The theory of NLHs provides a baseline for understanding what qualifies as a hub, while noting that indigenous theory of hubs is useful - elegant even-because of its vacuousness. Yet as an analytical tool, the theory does not go far enough. Where does one draw the line between, say, international arbitration houses, and NLHs proper? What are the key drivers of hubs and what are the main constraints on NLHs in terms of their growth? To these ends, I propose a continuum of NLHs to explain some of their differences, including why some fail and others attain varying degrees of success.

NLHs fundamentally reflect the interests of transnational actors, including not just the architects of hubs (host governments, U.K. legal consultants, and transnational legal elite) but also the parties themselves trying to facilitate cross-border deals in regions that

\footnotetext{
${ }^{104}$ Interview, Oxford, May 11, 2018.

${ }^{105}$ Christian De Cock, et al., Financial Phantasmagoria: Corporate Image-Work in Times of Crisis, 18 ORGANIZATION 153 (2011).

${ }^{106}$ See SWEET \& GRISEL, supra note 96, at 48-49. See also DEZALAY \& GARTH, supra note 32; Emmanuel Gaillard, Sociology of International Arbitration, 31 ARB. INT'L 1, 2 (2015).
} 
may otherwise be prone to bad law. ${ }^{107}$ NLHs can, broadly speaking, be categorized as "organic" or "artificial." The organicity and artificiality of hubs are points on a continuum, rather than "ideal types." 108 A number of variables differentiate the two categories, including time and the nature of the market. For the former, organic hubs have evolved over a longer period of time, and tend to have more mature legal service industries. They are supply-driven. The dense supply of legal services establishes the reputation of the NLH. In a kind of path dependence, the more that a certain jurisdiction supplies the legal services, the more demand grows. ${ }^{109}$ Artificial hubs are newer; their host states may have lower levels of socioeconomic development, and are thus more focused on generating demand. In artificial hubs, there are also lawyers who supply the law, but the legal services industry is less mature than in organic hubs.

One point of differentiation between organic and artificial hubs is the extent to which the host state was historically part of empire. International law scholars have noted the inheritance of international law, and foreign investment law, in particular, from empire, and specifically, the British Empire. ${ }^{110}$ The proto-TLO of the British Empire underpins the post-TLO decentralized configuration of NLHs. Within that configuration, the host states of organic hubs were British possessions for longer, and tend to have legal systems that draw more explicitly from English common law and courts that continue to cite English authorities, including the U.K. Supreme Court and the Privy Council. Moreover, they adopt the court ceremonies and rituals of English law to draw on the legitimacy of English law. As host states of artificial NLHs have a weaker connection to the British Empire, these elements are attenuated.

Globalization has not created a "flat" landscape of NLHs; there are tiers. ${ }^{111}$ The quality of hubs is determined by legal infrastructure, legal services, and legal culture. ${ }^{112}$ Legal infrastructure refers to the core institutions of the legal system and their material bases, so, for example, courthouses, arbitration hearing rooms, and the technology that supplements these institutions (e.g., case management systems, e-filing, etc.) Legal services refer to the provision of support for transactions and dispute resolution (i.e., lawyers, judges, arbitrators, and mediators). Legal culture encapsulates the degree to which law permeates the behavior of the society in which the NLH is embedded. Even if

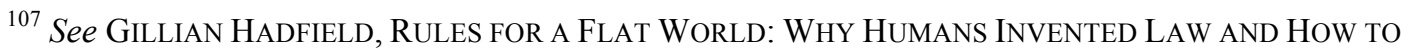
REINVENT IT FOR A COMPLEX GLOBAL ECONOMY (2016) (proposing the construction of a legal architecture in a period of globalization).

${ }^{108}$ Max Weber, Objectivity in the Theory of the Social Sciences and of Social Policy, in GESAMMETLE AufsaetZe Zur WissenschafTSLEHRE 146, 190-92 (1922).

${ }^{109}$ See Oona A. Hathaway, Path Dependence in the Law: The Course and Pattern of Legal Change in a Common Law System, 86 IOWA L. REV. 101 (2003) (arguing for the role of path dependence in understanding legal evolution); Kwai Hang Ng \& Brynna Jacobson, How Global Is the Common Law? A Comparative Study of Asian Common Law Systems-Hong Kong, Malaysia, and Singapore, 12 ASIAN J. COMP. L. 209, 212 (2017) (arguing that English common law spread because it was imported and is selfreferential).

${ }^{110}$ José E. Alvarez, Contemporary Foreign Investment Law: An 'Empire of Law' or the 'Law of Empire', 60 Ala. L. ReV. 943 (2009); ANTONy ANGHie, IMPERIAlism, SOVEREIGNTy, AND THE MAKING OF INTERNATIONAL LAW (2004); LAUREN BENTON \& LISA FORD, RAGE FOR ORDER: THE BRITISH EMPIRE AND THE ORIGINS OF INTERNATIONAL LAW, 1800-1850 (2016).

${ }^{111}$ See Pistor, supra note 84.

${ }^{112}$ My analytical framework is inspired by the comparative sociology of legal professions. See Philip S.C. Lewis, Introduction, in LAWYers In SOCIETy: The COMMON LAW WORLD 1 (Richard L. Abel \& Philip S.C. Lewis eds., 1988).
} 
local law is not the governing law of the parties' contracts, then attitudinal preferences shape social practices of law. Legal infrastructures are the quickest to establish, particularly in autocratic states, legal services are a slow build, and legal culture is the most elusive. Within these parameters, I examine a number of specific metrics to gauge, in particular, the depth and breadth of legal services. While statistical measures are helpful, I foreground qualitative data.

To provide a snapshot preview of my analysis, based on the above parameters, Hong Kong is the most organic of NLHs with Singapore as somewhere between organic and artificial. The rest of the hubs that I analyze, including Shanghai, Shenzhen, and Dubai and Astana are increasingly artificial, in that order. Further, while NLHs are arranged in a decentralized system, it is clear that certain hubs are more prominent than others. Hong Kong and Singapore are top tier hubs. Lower tier hubs include Dubai, Astana, Shenzhen, and Shanghai (Figure). In the remainder of this part, I provide my analysis of this continuum.

Insert Figure here.

\section{A. Hong Kong}

The oldest, most organic, and most mature NLH is Hong Kong. Hong Kong is supply rich, and its geographic location has rendered it conducive to high volumes of transactions and yet has made it vulnerable to the larger polities from which it is derived. Hong Kong is a result of two overlapping geographies of influence: Britain, which established Hong Kong as a colony a year after the Treaty of Nanking in August 29, $1842,{ }^{113}$ and China, whose imperial dynasties had a much longer history of influence over the island. Hong Kong's unique position as poised between two competing empirenations has been formative of its legal culture, one that has proved attractive over the past forty years to foreign investors accessing the Chinese market. ${ }^{114}$ Yet since Xi Jinping assumed control of the PRC, Chinese influence over the Hong Kong legal system has jeopardized Hong Kong's reputation as a legal hub.

Hong Kong is an exceptional jurisdiction and is linked historically to the City of London (hereinafter, "the City") through the processes of empire-building. It was trading houses like Jardine, Matheson \& Co. who, with the aid of Chinese compradors, established its head office in Hong Kong in 1844 (and whose limited company of merchant bankers, Matheson \& Co., was founded in 1848 in the City), which laid the foundations for Hong Kong's position as Britain's "gateway on the east." ${ }^{115}$ During this time, the common law legal system and English language were exported to the colony via British constitutional law, substantive laws that were copied in local ordinances, and acts of Parliament. ${ }^{116}$ Although law was of superficial importance during this period, a small legal community eventually took root. ${ }^{117}$ It was not until the 1970 s and 1980 s that Hong

\footnotetext{
${ }^{113}$ Benny Y.T. Tai, Maintaining a Common Law Legal System in a Non-Western Culture, in LAW AND LEGAL InSTITUTIONS OF ASIA: TRADITIONS, ADAPTATIONS AND INNOVATIONS 62, 64 (E. Ann Black \& Gary F. Bell eds., 2011).

${ }_{114}^{114}$ See supra note 31, at 174 (2d ed. 2013).

115 Elisabeth Sinn \& Christopher Munn, Meeting Place: Encounters Across Cultures in Hong KONG, 1841-1984 (2017).

${ }^{116}$ Christopher Munn, Anglo-China: Chinese People and the British Rule in Hong Kong, $1841-$ 1880 chs. 3-5 (2001).

${ }^{117}$ See DeZALAY AND GARTH, supra note 67 at 212.
} 
Kong's legal services grew. The real estate boom of the 1980s, the diversification of Hong Kong businesses, the entry of British and American law firms, and increasing Chinese investment, all spurred the internationalization and liberalization of Hong Kong's legal services. Hong Kong's court system was directly integrated into the English court hierarchy with the Privy Council serving as final appellate court in Hong Kong and international commercial arbitration became a focus of the colonial government in the 1980s. ${ }^{118}$

With the handover of Hong Kong from Britain to China in $1997,{ }^{119}$ the Hong Kong Special Administrative Region (HKSAR) was established, predicated on the notion of "one country, two systems." "20 The Basic Law of the HKSAR, Hong Kong's miniconstitution, provides that the HKSAR shall have a "high degree of autonomy and enjoy executive, legislative and independent judicial power" and that the "laws previously in force in Hong Kong, that is, the common law...shall be maintained."121 Changes have occurred, however, including limited reforms introduced in the court, ${ }^{122}$ and the use of Cantonese (alongside English) as the language of courts. ${ }^{123}$ Yet the most strident change has been the exercise of the National People's Congress's (NPC's) power to interpret the Basic Law. ${ }^{124}$

Because of Hong Kong's jurisdictional status as a "special administrative region," its relationship to the mainland is constructed through soft law agreements, based on article 95 of the Basic Law. Two of the most important include the following: the Arrangement on Reciprocal Recognition and Enforcement of Judgments in Civil and Commercial Matters by the Courts of the Mainland and of the Hong Kong Special Administrative Region Pursuant to the Choice of Court Agreements between Parties Concerned, signed on July 14, 2006 (hereinafter "Court Arrangement") and the Arrangement Concerning Mutual Enforcement of Arbitral Awards Between the Mainland and the HKSAR, signed on June 21, 1999 (hereinafter "Arbitration Arrangement"). The prevalence of soft law in NLHs, then, is not only a result of NLHs being financial hubs, but also their dependent status. Given that most NLHs are not granted full state status under international law and thus hubs cannot sign treaties, such soft law defines hubs and their legal relationships with states (and other hubs). Soft law, not unlike hard

\footnotetext{
${ }^{118}$ See Tai, supra note 113, at 68; Neil Kaplan, The History and Development of Arbitration in Hong Kong, 1 Y.B. INT'L FIN. \& ECON. L. 203, 206-07 (1996) (describing how the passage of the Arbitration (Amendment) Ordinance 1982 provided the legislative basis for the Attorney General to develop Hong Kong as an "international arbitration centre").

${ }^{119}$ See Joint Declaration of the Government of the United Kingdom of Great Britain and Northern Ireland and the Government of the People's Republic of China on the Question of Hong Kong, effective Dec. 19, 1984.

${ }^{120}$ See Tai, supra Tai note 113, at 67 (explaining that the idea of "one country, two systems," as developed by Deng Xiaoping, is given constitutional status in article 31 of the PRC Constitution).

${ }^{121}$ Basic Law of the Hong Kong Special Administrative Region of the People's Republic of China, adopted at the third session of the seventh National People's Congress on Apr. 4, 1990, effective July 1, 1997, arts. 2 and 8.

${ }^{122}$ See Tai, supra note 113, at 68 (the Hong Kong Court of Final Appeals replaced the Judicial Committee of the Privy Council).

${ }^{123}$ See Kwai Hang Ng, The Common Law in Two Voices: Language, Law, and the Postcolonial Dilemma IN HONG KONG 3 (2009) (identifying post-1997 Hong Kong as officially a bilingual legal system).

${ }^{124}$ See supra Basic Law note 121 at arts. 17 and 158 (conferring interpretive oversight of the Basic Law to the Standing Committee of the NPC).
} 
law and perhaps more so, is open to political intervention, and Hong Kong is no exception in this regard.

Before and after the handover, Hong Kong has earned a reputation as an easy place for doing business, its legal system being a guarantor of transactional security. ${ }^{125}$ When I practiced law in Beijing, it was common to advise non-Chinese companies who wanted to do business in China to first establish investment vehicles in Hong Kong that then set up entities in the mainland, an approach that renders it easier to do any restructuring offshore without requiring approvals from PRC authorities. Today, Hong Kong has a liberalized legal industry servicing Hong Kong's corporate and financial sectors, including 10,896 lawyers, 9463 of whom possess a practicing certificate and 1433 registered foreign lawyers. ${ }^{126}$ There are some 1065 law firms in Hong Kong, including 892 Hong Kong law firms and 84 registered foreign law firms. ${ }^{127}$ With these services, Hong Kong is the largest FDI source in China. ${ }^{128}$

Hong Kong's position as NLH has changed in recent years; whereas facilitating FDI into China is still a major function of the hub, it increasingly services Chinese outbound investment. Starting in 2014, PRC replaced the United States as the number one origin of foreign companies choosing Hong Kong to either establish or expand their operations. ${ }^{129}$ PRC firms, particularly in the industries of finance, real estate, and telecomm, have begun to eclipse Hong Kong companies and British conglomerates. ${ }^{130}$ As a result of mainland dominance of select Hong Kong industries, in recent years, Hong Kong has become the largest overseas RMB offshore market. ${ }^{131}$

Hong Kong as a jurisdiction for resolving disputes related to PRC parties demonstrates the contingency of an expanding Chinese presence in Hong Kong. On the plus side, Hong Kong law, as the choice of law, is often a compromise between a U.S. or U.K. party that elects New York or U.K. law and a Chinese party that opts for Chinese law. Lawyers typically advise clients to use the Hong Kong common law, rather than PRC civil law. ${ }^{132}$ Hong Kong dispute resolution mechanisms also benefit from its middleman position. Hong Kong courts are widely regarded for their competence. Hong Kong does not have an "international commercial court," as legal industry insiders view the Hong Kong Court of Final Appeal (HKCFA) as an international commercial court if it is defined as featuring foreign judges on its bench (the HKCFA features judges from

\footnotetext{
${ }^{125}$ See World Bank, Doing Business Index, http://www.doingbusiness.org/rankings (ranking Hong Kong fifth in the world) (last visited Sept. 4, 2018).

${ }^{126}$ The LAW SOCIETy OF HONG Kong, ANNUAL RePOrT 6-7 (2017).

${ }^{127}$ Id.

${ }^{128}$ Melissa Kaye Pang, Hong Kong as a Base for Doing Business in Mainland China, Am. BAR Ass'N (June 1, 2013), https://www.americanbar.org/publications/blt/2013/06/01_pang.html.

129 Cannix Yau, Hong Kong's Future Lies in Helping Chinese Firms Go Global, Official Investment Advisor Says, S. ChInA MoRning Post (Nov. 26, 2017), https://www.scmp.com/news/hongkong/economy/article/2121607/hong-kongs-future-lies-helping-chinese-firms-go-global (citing statistics from the HKSAR Government's official investment promotion body that in 2016, 391 PRC companies either set up or expanded in Hong Kong, an all-time high of a 4.3\% increase on 375 firms from the previous year).

${ }^{130}$ Prudence Ho, Chinese Giants Are Taking over Hong Kong, BloOMBERG (June 6, 2017), https://www.bloomberg.com/news/features/2017-06-06/chinese-giants-are-taking-over-hong-kong.

${ }^{131}$ Hudson Lockett, UK Becomes Second-Largest Offshore RMB Clearing Centre, Fin. TIMES (Apr. 27, 2016), https://www.ft.com/content/d552173a-6030-3c83-b4f7-9efc1819bb30 (explaining that Hong Kong processes $72.5 \%$ of all RMB payments in 2015 ).

${ }^{132}$ E-mail correspondence, July 23, 2018.
} 
other common law countries). For purposes of dispute resolution clauses, foreign parties usually prefer arbitration, either the Hong Kong International Arbitration Centre (HKIAC) or the ICC. The, HKIAC, established in 1985, is a leading seat for international arbitration in Asia and one of the top five houses in the world. ${ }^{133}$ In 2017, 297 arbitration cases were filed with the HKIAC, a $15.7 \%$ increase from the previous year, 156 of which were administered by HKIAC Rules or UNCITRAL Arbitration Rules. ${ }^{134}$ Of those cases, $73.1 \%$ of the cases involved at least one foreign (i.e., non-Hong Kong) party, and 40.8\% involved no Hong Kong party. ${ }^{135}$ The total amount in dispute in all cases was US\$5 billion, twice the amount arbitrated in 2016 (US\$2.5 billion), ${ }^{136}$ for an average sum in dispute of nearly US\$1.7 million. Hong Kong courts have a strong reputation for upholding arbitral awards.

On the negative side, enforcement of Hong Kong judgments and arbitral awards can be problematic in the mainland. ${ }^{137}$ The Court Arrangement provides for PRC courts to enforce the judgments of Hong Kong courts, the only such reciprocal agreement between the PRC and a common law jurisdiction. ${ }^{138}$ In 2010, a Shanghai court was the first to recognize a Hong Kong court judgment. ${ }^{139}$ Despite this positive sign, some lawyers I spoke to voiced concerns about limitations on PRC courts' recognition of Hong Kong judgments under the Court Arrangement. Other lawyers were even more pessimistic and advised clients to opt for arbitration. Yet enforcement of Hong Kong arbitral awards can likewise be troublesome. Under the Arbitration Arrangement, the main issue is not the recognition of a non-PRC award; ${ }^{140}$ rather, it is the enforcement of a Hong Kong award by a PRC court against a Chinese party that is difficult. ${ }^{141}$

Members of the Hong Kong legal industry, including both government officials and private practitioners, are keenly aware of Hong Kong's status as an evolving NLH and explicitly market it as such, increasingly for mainland businesses. The HKIAC has been aggressively advertising its services for the BRI, including launching an online "Belt and Road Resource Centre," ${ }^{142}$ providing tailored model arbitration clauses under both the HKIAC Administered Arbitration Rules and the UNCITRAL Rules, ${ }^{143}$ and conducting "road shows" in BRI countries. As a result of these efforts, the HKIAC has

\footnotetext{
${ }^{133}$ See Queen Mary supra note 3, at 2.

${ }^{134}$ Hong Kong Int'1 Arb. Centre, 2017 Statistics, http://www.hkiac.org/about-us/statistics. 
been one of the most successful international arbitration houses in attracting BRI deals, some 362 from 2014 to 2017 (Table 1). Further, between those years, the percentage of overall arbitration matters involving PRC parties has averaged 36.7\%, with a high in 2015 of 135 matters or $49.8 \%$ of all matters (Table 2). ${ }^{144}$

Insert Table 1 and Table 2 here.

The HKIAC is not alone in advertising its services for BRI deals. Government representatives and lawyers became para-ethnographers in their analyses of emergent trends. ${ }^{145}$ They bring quasi-social scientific analysis to bear on questions framed foremost by market incentives and sotto voce politics. The BRI is the litmus test for the recalibration of Hong Kong as a NLH. I provide three brief sketches:

\section{The HKSAR Government}

"Hong Kong's strength is functioning as a legal hub for the BRI," the government official sitting across from me states in a matter-of-fact tone. I am sitting in the office of the Hong Kong Trade Development Council (HKTDC), the promotional arm of the HKSAR, with the official and her colleague, recently promoted to head "Belt and Road and External Relations." "Hong Kong is the risk management center for the BRI," she continues, "Chinese SOEs use Hong Kong to establish a sub, launch an IPO, and then list their shares on our stock exchange. They file lawsuits here and use our arbitration, particularly for IP and construction." ${ }^{146}$ The official prompts me to sift through the promotional material on their annual summits, attended by three thousand people, which also promotes the BRI. The summit serves to provide a platform for "business matching," between Chinese companies and those of host states. During the summit, the HKDOJ organizes two workshops on legal services and arbitration. These functions-business matching and dispute resolution - also have online equivalents. ${ }^{147}$ Not only does the HKTDC online portal have some two hundred Hong Kong-based service providers (including law firms, accountants, translators, and notaries) but it is also developing an online arbitration center for BRI disputes.

\section{The bar}

"The central government provides the vision. We add the brick and mortar," a leading member of the Hong Kong Law Society's (HKLS's) "Belt and Road Committee" tells me. The HKLS, established in 1907, is the professional organization of solicitors in Hong Kong. Over the past several years, it has been the fulcrum point in a debate about the political identity of lawyers in the HKSAR. ${ }^{148}$ The "Belt and Road Committee" was formed in 2015 with the goal of promoting Hong Kong as a legal hub and also facilitating the harmonization of trade and business law between China and Hong Kong. More broadly, a purpose of the HKLS is to create links with counterparts in the mainland, namely, the China Law Society and the All China Lawyers Association through

\footnotetext{
${ }^{144}$ E-mail correspondence with the HKIAC (Mar. 6, 2018).

${ }^{145}$ Cf. Miyazaki, supra note 73 .

${ }^{146}$ Interview, Hong Kong, Mar. 29, 2018.

${ }^{147}$ See Hong Kong Trade Development Council, The Belt and Road Portal, http://beltandroad.hktdc.com/en/ (last visited Oct. 22, 2018).

${ }^{148}$ See, e.g., Man Yee Karen Lee, Beyond the "Professional Project": The Political Positioning of Hong Kong Lawyers, 50 InT'L J. L., CRIME \& JUSTICE 1 (2017).
} 
continuing legal education. This goal dovetailed with those of the Belt and Road Committee in an international conference sponsored by the HKLS on May 12, 2017, called, "The Belt and Road: A Catalyst for Connectivity, Convergence and Collaboration." During the conference, much was made of Hong Kong's common law tradition as a guarantor for quality of legal services in the context of the BRI. ${ }^{149}$ At the end of the conference, participants signed a "Hong Kong Manifesto," to promote legal cooperation between lawyers from BRI states. ${ }^{150}$

\section{A corporate lawyer}

"Hong Kong has been a legal hub for a long time. Depending on how you define it, at least for twelve years or more...But the fear of every middleman is being cut out. Does China really need Hong Kong lawyers? Does it really need Hong Kong finance?"151 The Hong Kong lawyer sitting in front of me in his law office answers both of his own questions with a shoulder shrugging "no." A partner at a major international law firm, the lawyer identifies Hong Kong's status as a legal hub as deriving from the promotion of its facilities, quality legislation, and the esteemed position of its arbitrators. However, he expressed skepticism about the BRI. "There is a view," he said, while tilting his head and pausing for effect, "that the BRI is mainly geo-strategic or political and there is not enough money." He further mentioned that private banks have been reluctant to become involved suggesting that they fail to see the commercial value of the proposed projects. The lawyer concluded there will be more disputes, although many of these will be resolved through political means. Hence, while Hong Kong law firms and arbitration houses will gain some business from the initiative, the view of many practitioners is a tempered one.

The three sketches provide differing views on the work of promoting NLHs, the incentives behind that work, and its potential effects. The official view of the HKTDC is most in line with a Beijing-centric orientation of Hong Kong's legal services via the BRI. The spokespeople for the HKLS hold similar views, ${ }^{152}$ although perspectives from within the organization differ, as in the case of the corporate lawyer. For the HKTDC official and the HKLS representative, the concept "legal hub" had saturated their discourse. The problem is that the mirror imaging between experts' and the ethnographer's analytical terms can appear "readymade"; ${ }^{153}$ the analysis of the legal question (i.e., NLHs) becomes self-evident. For ethnography, this doubling of expertise is problematic as the methodology has traditionally proceeded through the translation of set of knowledge practices into another. Yet when legal professionals use concept terms like "legal hubs,"

\footnotetext{
${ }^{149}$ In keynote speeches, both Chun-ying Leung ("C.Y. Leung”), the third Chief Executive of Hong Kong, and Rimsky Yuen Kwok-keung, the then-Secretary of the HKDOJ, made comments to this effect. C.Y. Leung further quoted the words of Zhang Dejiang, Chairman of the Standing Committee of the PRC NPC who at a BRI Summit in Hong Kong on May 18, 2016 stated, "We support Hong Kong's efforts to build a center for international legal and dispute resolution services in the Asia-Pacific, in order to provide legal and arbitration services to the Belt and Road." Personal observation, Hong Kong, May 12, 2017. ${ }^{150}$ The Hong Kong Manifesto is signed by thirty-seven law associations, including a number of PRC regional lawyer associations.

${ }^{151}$ Interview, Hong Kong, Mar. 27, 2018.

${ }^{152}$ See also Hong Kong Policy Research Institute, Hong Kong as an International Legal Hub: Opportunities from the "Belt and Road" Initiative (Sept., 2016) (on file with the author) (providing a similar view from a conservative think tank).

${ }^{153}$ See supra note 65 , at 41 .
} 
these are hardly value-neutral invocations, and such values or politicizations can be imported into one's analysis, presenting challenges to the ethnographer who aspires to arm's-length objectivity.

My response to this problem, and the broader point for understanding how NLHs resituate conflict of laws, is that triangulating how different actors use hubs shows that the self-promotion of hubs, which is constitutive of their attractiveness as a choice of law and forum for dispute resolution, is contingent. Experts occupy "different relationship configurations of power and collegiality," 154 and ethnography draws attention to these positions.

\section{B. Singapore}

The other mature NLH and one that lies in between the organic and artificial ends of the spectrum is Singapore. Singapore is the major rival to Hong Kong as the legal hub of Inter-Asia, and this relationship of competition has shaped both jurisdictions, particularly as they vie to service the legal needs of outbound Chinese capital. Singapore has a more top-down approach to hub-building than does Hong Kong. Whereas the government claims to have a Westminster-style parliament, in fact, the People's Action Party (PAP) has led the government since 1959. Singapore is thus a hybrid regime, and one that has commandeered the slogan "legal hub" in its infrastructural sense. What Singapore lacks in the depth of its legal culture in comparison to Hong Kong, it makes up in its legal infrastructure, and Singapore is making gains on Hong Kong.

Singapore's growth as a NLH is a story of scale and government. Like Hong Kong, Singapore's past is colonial, a past that has shaped its contemporary adoption of common law. The British East India Company under Sir Thomas Stamford Raffles secured a free port in Singapore in 1819 to transport cotton, silk, saltpeter, and other goods from the subcontinent. Singapore's status as a free port depended on its geographic location and also its relative small size as a landmass. At 719 square kilometers, Singapore is not even a third the size of Hong Kong island (2754 sq. km). With a population in 2018 of 5.7 million people, Singapore has one of the highest population densities in the world (at 2069 people per sq. km). Amidst this density, the legal sector employed 13,100 people (or $6 \%$ of the total), comprised $8 \%$ of value-add, and generated S\$2.1 billion (US $\$ 1.5$ billion) in that same year. ${ }^{155}$ In 2017 , there were 3,646 licensed lawyers working at 409 legal practices in Singapore. ${ }^{156}$ Not unlike Hong Kong, the government is actively involved in all aspects of the legal profession, including dispute resolution. The government has liberalized the legal service sector to enhance Singapore's position in macroregional trade. ${ }^{157}$ Lawyers benefit from the positive effects

${ }^{154}$ Tara Schwegler \& Michael G. Powell, Unruly Experts: Methods and Forms of Collaboration in the Anthropology of Public Policy, 1 ANTHROPOLOGY IN ACTION 1, 8 (2008).

${ }^{155}$ EDB Singapore, Singapore's Professional Service Industry to Lead Globally in High-Value, Specialist Services 6-7 (Jan. 24, 2018), https://www.gov.sg/ /sgpcmedia/media_releases/edb/press release/P20180123-1/attachment/FINAL-Press\%20Release\%20-\%20Professional\%20Svcs\%20ITM-24Jan2018.pdf.

${ }^{156}$ Lawyers include both Singaporean and foreign-licensed operating in Singapore; "law practices" includes Singaporean law firms, foreign law firms, joint ventures, and representative offices. See Singapore Ministry of Law, Legal Services Regulatory Authority E-Services, https://www.mlaw.gov.sg/eservices//sra/searchlawyer-or-law-firm/ (last visited Aug. 30, 2018).

${ }^{157}$ Pasha L. Hsieh, Liberalizing Trade in Legal Services under Asia-Pacific FTAs: The ASEAN Case, $18 \mathrm{~J}$. INT'L ECON. L. (2015). 
of such agglomeration: shoulder-rubbing, business generation, and public-private cooperation. The result of is conveyed in an account told to me by a foreign lawyer who is a partner in an international law firm:

On my first day practicing here, a recently seconded associate who came from the government told me there was a talk on treaty interpretation at a hotel and asked me if I'd like to go...The hotel conference room was packed. There were some 150 people there. That was the first thing that struck me. You would not find that level of interest in cities like Tokyo or New York. The second thing was the access to high-ranking officials. After the talk, before I knew it, I was sitting with the associate and the attorney general discussing treaty interpretation. This was on my first day! ${ }^{158}$

The partner has since gone on to have a lucrative career in international arbitration.

A corollary of Singapore's economy is that the domestic legal market is relatively small; as a result, the government has actively promoted the internationalization of the legal services industry, a goal that operates in tandem with the priority of placing Singapore as a world leader in banking and finance, asset management, and capital markets. Governmental investment in dispute resolution services has both positive and negative effects. On the downside, the neutrality of Singapore's courts has been questioned, particularly in politically sensitive cases. ${ }^{159}$ On the upside, to provide attractive dispute resolution mechanisms, the Supreme Court of Singapore and the Ministry of Law have developed "a suite of services" including the Singapore International Arbitration Centre (SIAC, est. 1991), the Singapore International Mediation Centre (SIMC, est. 2014), and the Singapore International Commercial Court (SICC, est. 2015). The SIAC-SIMC-SICC trifecta is an example of top-down institution-building. As such, the SIAC, SICC, and SIMC have evolved as dispute resolution mechanisms together and have coordinated cross-institutional links and hybridized procedures, defining elements of NLHs. Hubbing endeavors to insulate specialized dispute resolution from problems that plague the rest of the legal system (e.g., insufficient judicial independence).

The suite, its centrality to Singapore as a hub, and its conflict of laws innovations can best be understood in terms of legal infrastructure. As early as 1990, as part of Singapore's development model, the founding Prime Minister, Lee Kuan Yew, identified the bar as a focus for internationalization. ${ }^{160}$ Some ten years later, the Ministry of Law made a push for Singapore to become a leader in international commercial arbitration in Asia, ${ }^{161}$ and in 2006, established the Committee to Develop the Singapore Legal Sector (CDSLS). The CDSLS, comprised of such members as Mr. Michael Hwang, currently the Chief Justice of the DIFC Courts, established four working groups: the Legal Education

\footnotetext{
${ }^{158}$ Interview, Singapore, Aug.13, 2018.

159 See Mark Tushnet, Authoritarian Constitutionalism, 100 CORNELL LAW REVIEW 391, 403 (2015).

${ }^{160}$ See Anon., Use Technology to Tap Legal Expertise Worldwide, STRAITS TIMES (Sept. 1, 1990) (citing Prime Minister Lee's speech at the opening of the Singapore Academy of Law), Anon., Legal Hubs? S'pore Has What It Takes, STRAITS Times 10 (Apr. 11, 2002).

${ }^{161}$ See Rachel Chiu Li Hsien, Clothing the Bare: The Enforcement of Arbitration Clauses in Singapore, (Mar. 2, 2018), https://blogs.law.nyu.edu/transnational/2018/03/clothing-the-bare-the-enforcement-ofarbitration-clauses-in-singapore/\#_ftn2 (citing Court of Appeal judgment in Tjong Very Sumito v Antig Investments [2009] 4 SLR(R) 732, [28], “An unequivocal judicial policy of facilitating and promoting arbitration has firmly taken root in Singapore.”)
} 
Working Group, the Legal Infrastructure Working Group, the Legal Profession Working Group, and the Working Group to Promote Singapore as a Legal Services Hub. ${ }^{162}$

Around this time, the concept of "legal hub" peppered parliamentary debates and the "legal year speeches" given by such officials as the Attorney General, President of the law society, and the Chief Justice, as well as the media. ${ }^{163}$ Meanwhile, under the CDSLS, the Working Group to Promote Singapore as a Legal Services Hub, in conjunction with the Legal Infrastructure Working Group, solicited views of Singaporean and foreign arbitrators and barristers practicing in Singapore in terms of their views on growing Singapore's capacity for international arbitration. ${ }^{164}$ The idea of the legal hub began to concretize around the concept of a building that could be the site for sophisticated dispute resolution.

The Ministry of Law decided on the former British customs building and a heritage site for what would become known as Maxwell Chambers, the first-of-its-kind international commercial dispute resolution center, which officially opened on January 21, 2010. On my first visit to Maxwell Chambers, I was surprised to see a plaque near the original entrance of the building, stating

\section{CUSTOMS HOUSE, MAXWELL ROAD}

This was the headquarters of Singapore Customs from 1932 to 1989. Formerly known as the Government Monopolies Department, the Customs collected duties levied on selected imported goods such as opium and liquor. It banned opium after the Second World War due to societal problems caused by the drug. The Custom House also housed the Film Censor's Office and the Maxwell Road Post Office.

Below the description is an image, dated 1974, of four customs officers in bell-bottoms and polyester shirts squatting over a large haul of opium.

Maxwell Chambers, as nodal point for Singapore's legal globalization, draws on the bygone glory of an imperial past (even if it was an empire that trafficked in vice). Today, Maxwell Chambers is spatially located to maximize its attractiveness to users. Maxwell Chambers includes two kinds of spaces: one, hearing rooms for arbitration and mediation and, two, office spaces for dispute resolution service providers. Located in the central business district, approximately twenty-five minutes from the airport and fifty meters from the nearest mass rapid transit stop, Maxwell Chambers offers convenience to parties and arbitrators. Legal infrastructure informs urban planning; nearby hotels and restaurants provide additional services to users. ${ }^{165}$

The main attraction of Maxwell Chambers is that — according to its advertisements, as a "one-stop shop"166 - it houses under the same roof, most of the major Singaporean and international dispute resolution institutions, in effect, maximizing

\footnotetext{
${ }^{162}$ See Report of the Committee to Develop the Singapore Legal Sector, Sept. 2007, on file with the author.

${ }^{163}$ See, e.g., Singapore Law Watch, About Singapore Law, (Jan. 15, 2006), http://www.singaporelawwatch.sg/About-Singapore-Law.

${ }^{164}$ Interview with Maxwell Chambers executive, Singapore, Aug. 13, 2018.

${ }^{165}$ But see Global Arbitration Review, Guide to Regional Arbitration (volume 6-2018) Survey Results, (Nov. 17, 2017), https://globalarbitrationreview.com/insight/guide-to-regional-arbitration-volume-62018/1150108/survey-results (identifying Maxwell Chambers as not having the ideal location in the city).

${ }^{166}$ Personal observation, Aug. 13, 2018.
} 
the agglomeration effect and minimizing transaction costs for potential clients. These include the SIAC and SIMC, as well as the ICC, the International Centre for Dispute Resolution, the Singapore Chamber of Maritime Arbitration, the World Intellectual Property Organization Arbitration and Mediation Center, and several commercial barristers' chambers, the majority of which are headquartered in the City. In accordance with what economist Michael Porter has called "cluster theory," competitors, such as arbitration houses, benefit from physical proximity, which stimulates competition and innovation while lowering transaction costs and thus delivering better services to consumers. ${ }^{167}$ The physical proximity of the dispute resolution service providers within Maxwell Chambers, itself a quasi-state-run corporation, ${ }^{168}$ has enabled a certain degree of cross-institutional coordination.

An example given by representatives of the Ministry of Law is the procedural merger of arbitration and mediation. When the SIMC was established in 2015, it joined a new protocol with the SIAC that provided for a procedure called "Arb-Med-Arb." The Arb-Med-Arb protocol joins the advantages of mediation, specifically, convenience, flexibility, and low cost, with the main benefit of arbitration, enforcement (i.e., a consent award is recognized by the arbitral tribunal and as such is enforceable under the New York Convention). While Arb-Med-Arb is not without its problems, ${ }^{169}$ the Ministry of Law has been broadly successful in branding the protocol, and, as an instance of continual innovation, is spearheading an UNCITRAL Convention on the Enforcement of Mediation Settlements that is to be called the "Singapore Mediation Convention," the mediation industry's equivalent of the New York Convention. ${ }^{170}$ Cross-institutional links enhance enforcement and increase the appeal of Singapore as a venue for dispute resolution.

Procedural innovation is supplemented by virtual equivalents. Maxwell Chambers launched "SMART Maxwell" in 2018, which mobilizes technology to maximize convenience and "boost Singapore's position as an international dispute resolution hub." "171 Specific enhancements include an app users can download to their smartphone that obviates users from spending "up to half an hour collecting the physical access cards and distributing them to each business representative, legal counsel, arbitrator and/or mediator... The total cost savings from the smart solutions are estimated to be over half a million dollars a year." 172

Because of the foregoing, Singapore has made significant strides in billing itself as a destination for international commercial dispute resolution. While the Ministry of Law promotes Singapore's dispute resolution services broadly (e.g., to the Association of

\footnotetext{
${ }^{167}$ Michael Porter, COMPETitive AdVANTAge of Nations (1990).

${ }^{168}$ Maxwell Chambers is officially a commercial entity, specifically, a publicly limited company but it does not so much as to update its websites without consulting the Ministry of Law.

${ }^{169}$ One issue raised by several practitioners I spoke to is whether the arbitrator and mediator are one in the same person in which case information gleaned during the mediation could prejudice the arbitrator's decision making.

${ }^{170}$ SIMC, The Singapore Convention: A Milestone in Mediation, (Oct. 18, 2018), http://simc.com.sg/singapore-convention-milestone-mediation/ (stating that the Singapore Mediation Convention is to be effective as of August 1,2019).

${ }^{171}$ Singapore Ministry of Law, Maxwell Chambers Innovates to Become World's First Smart Hearing Facility, (Apr. 4, 2018), https://www.mlaw.gov.sg/content/minlaw/en/news/press-releases/maxwellchambers-world-first-smart-hearing-facility.html. ${ }^{172} I d$.
} 
Southeast Asian Nations (ASEAN) states, India, etc.), Singapore is also competing with Hong Kong to hitch itself to the lodestar of the BRI. Repeatedly, Singaporean officials mentioned the "33-85" figure, meaning that thirty-three percent of all outbound investment under the BRI goes through Singapore, and eighty-five percent of all inbound investment to China similarly arrives via Singapore. Given the importance of the SinoSingaporean relationship, the Ministry of Law organizes the SIAC-SIMC-SICC suite to conduct united road shows to China as well as BRI countries to showcase some of Singapore's cross-institutional links. Singapore is the only country besides the United Kingdom to hold an annual legal and judicial roundtable with the PRC. As a result of the second roundtable in Singapore in 2018, the Supreme Court of Singapore signed a Memorandum of Guidance (MOG) with the SPC for the recognition and enforcement of money judgments, the first such MOG the SPC has signed with another judiciary. ${ }^{173}$

Singapore's efforts to market its dispute resolution services in China appear to be paying off. In 2012 and 2014, Chinese parties were the most frequent users of the SIAC and in 2015-2017, Chinese parties have been second only to those from India. ${ }^{174}$ The Singapore Chamber of Maritime Arbitration has earned a reputation for handling maritime and transport disputes, and some institutional clients like the China National Offshore Oil Corporation have expressed their intent to hold their cases at Maxwell Chambers. Another sign of Singapore's attractiveness in the eyes of the Chinese is its capacity to serve as a model for China's own hubs. PRC delegations from Guangdong and Shanghai have toured Maxwell Chambers. Representatives of Maxwell Chambers told me that about ninety percent of the questions Chinese delegates asked were about the role of technology, ${ }^{175}$ a fixation that accords with technophilia in Chinese judicial reform. ${ }^{176}$ Physical agglomeration meets procedural, doctrinal, and even technological agglomerations. Singapore thus demonstrates some of the elements of organic hubs in its early history as a free port that have been shepherded by the strong hand of the PAP state (i.e., artificialized) in recent decades.

\section{Dubai}

Moving from top tier hubs to lower ones, the lower tier hubs are both larger in number and more embryonic. Most of these hubs receive strong support from the host state. Among these, one of the most radical experiments in designing a jurisdiction is the DIFC Courts. ${ }^{177}$ By way of background, the 1980s oil glut led Dubai, one of the seven emirates of the United Arab Emirates (UAE), to diversify its economy leading the emir to build a free zone in Jebel Ali as well as a finance hub, in part, based on the Singapore experience. ${ }^{178}$ The emir sought to repatriate Middle Eastern money managed in financial

\footnotetext{
${ }^{173}$ See Memorandum of Guidance Between the Supreme People's Court of the People's Republic of China and the Supreme Court of Singapore on Recognition and Enforcement of Money Judgments in Commercial Cases, signed Aug. 31, 2018. Compare with infra note 222 (regarding the first MOU between a non-PRC and a PRC court).

${ }^{174}$ Statistics analyzed from compiled SIAC annual reports.

${ }^{175}$ Interview, Singapore, Aug. 13, 2018.

${ }_{177}^{176}$ See infra text accompanying note 258.

${ }^{177}$ The DIFC Courts consist of a Court of First Instance and a Court of Appeal, which is the court of final appeal. See Law No. 16 of 2011, Amending Certain Provisions of Law No. 12 of 2004 Concerning Dubai International Financial Centre Courts (hereinafter "Dubai Law No. 16"), art. 5(A), (B), available at https://www.difccourts.ae/2011/10/31/law-no-16-of-2011-amending-certain-provisions-of-law-no-12-of2004-concerning-dubai-international-financial-centre-courts/.

${ }^{178}$ Interview, London, Nov. 6, 2017.
} 
hubs in London and New York back to Dubai. To do so, and to secure FDI and encourage international banks to lend in Dubai, the government founded its own stock exchange and created a regulatory environment that would be familiar to institutional investors. However, Dubai is a jurisdiction that contains elements that are alien to many multinational firms based elsewhere, namely, Arabic language and the legal system. ${ }^{179}$

The DIFC Courts, then, were an effort, led by the emir and U.K. lawyers and judges, to create a subnational jurisdiction that would attract foreign business parties to Dubai. This collaboration introduced English common law to an area known as the DIFC. In the English-language DIFC Courts, modeled after the London Commercial Court, judges, who are trained in English common law in Commonwealth countries, apply English common law procedural rules to cases and substantive law chosen by parties, including a "local law" called "DIFC law," the result of legislation and common law decisions. The DIFC Courts are part of a dispute resolution complex that includes international commercial arbitration institutions, some of which are "joint ventures" with London-based houses. The DIFC Courts are thus "islands of transnational governance", 180 designed in response to conflict of laws concerns, and that demonstrate both the potential and drawbacks of NLHs.

In the words of the current Chief Justice, "The DIFC is meant to be a home away from home. Wall Street, City of London, Hong Kong, Sydney-[we] want you to feel like you never left home." microenvironments of hypermodernity, the specific approach to the problem of legal and regulatory uncertainty is creating a jurisdictional carve-out that applies English common law. ${ }^{182}$ While historically British rule in the region was indirect, ${ }^{183}$ it nonetheless provided a basis for the valorization of British systems of rule. Today, there are some 2300 licensed advocates (UAE nationals) and legal consultants (foreigners) in Dubai, and among these, 465 who are registered with the Academy of Law of the DIFC. ${ }^{184}$

The first step ${ }^{185}$ for engineering the DIFC as a jurisdictional carve-out was a constitutional amendment that allowed any of the federal states to establish a "financial center," a more muscular version of a free zone, with its own governing rules. ${ }^{186}$

\footnotetext{
${ }^{179}$ UAE law is mainly civil law, influenced by the Egyptian experience, and which also recognizes sharia (Islamic law and ethics).

${ }^{180}$ Alec Stone Sweet, Islands of Transnational Governance, in ON LAW, POLITICS, AND JUDICIALIZATION 323 (Martin Shapiro \& Alec Stone Sweet eds., 2002).

${ }^{181}$ Interview, Oxford, May 11, 2018.

182 See, e.g., DIFC Court Law, DIFC Law No. 10 of 2004, ch. 2 (providing that the rules of evidence for proceedings are those applied in the courts of England and Wales) https:/www.difc.ae/files/1914/5448/9176/Court_Law_DIFC_Law_No.10_of_2004.pdf (last visited Oct. 22, 2018).

${ }^{183}$ Nasser Ali Ali-Bakheshi, British Policy Towards the Trucial Coast Emirates 1947-1955 38 (1999) (unpublished Ph.D. dissertation, University of Manchester, Department of Middle Eastern Studies) (explaining that the sheikh ruled over the emirate with little change after the British presence). See also HuSAIN M. Al-BAHARNA, BRITISH EXTRA TERRITORIAL JURISDICTION IN THE GULF 1913-1971 (1998).

${ }^{184}$ Government of Dubai, Legal Affairs Department, Directory, https://lps.legal.dubai.gov.ae/Portal/DirectorySearch?isrtl=false\# (last visited July 9, 2018); E-mail correspondence with Dispute Resolution Authority of the DIFC Courts, July 9, 2018.

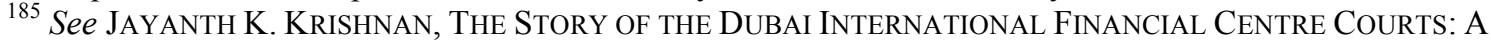
RETROSPECTIVE (forthcoming) (providing a history of the founding of the DIFC Courts).

${ }^{186}$ See United Arab Emirates's Constitution of 1971 with Amendments through 2004, art. 121, available at https://www.constituteproject.org/constitution/United_Arab_Emirates_2004.pdf.
} 
Consequently, the Ruler of the Emirate of Dubai, Sheikh Muhammad bin Rashid alMaktoun (hereinafter "the Sheikh"), established the DIFC in 2004. A statutory body, led by the Sheikh, hired Clifford Chance LLP and Allen \& Overy LLP, two leading British law firms, to draft the relevant legislation for the DIFC. While the firms drafted the statutes, a Queens Counsel (QC) wrote the more specific rules, based upon those of the London Commercial Court. ${ }^{187}$ Rules were not transplanted wholesale; for example, the QC substituted the International Bar Association rules of evidence for arbitration for the U.K. discovery rules. ${ }^{188}$ The first and current Chief Justices were both former members of Essex Court Chambers, based in the City. Hence, while it was mainly English solicitors and barristers who provided the technical expertise to lay the conceptual foundations of the DIFC Courts, it was very much a project spearheaded by local agency, suggesting a transplant that, in Jonathan Miller's terms, is both "entrepreneurial" and "legitimacygenerating." 189

The landmark innovation of the legal engineers of the DIFC Courts was designing an offshore jurisdiction for the financial center. Much like the corporate lawyers and merchant elite who, in the 1930s, designed the first tax-exempt companies in Bermuda and the Bahamas that would establish them as tax havens, ${ }^{190}$ local interests and U.K. legal experts in Dubai built the DIFC as an exception to the larger jurisdiction, in this case, the UAE. Their approach to designing an exceptional jurisdiction changed over time, in response to internal and external pressures. First, the approach to jurisdiction was what the first chief justice termed "geographic."191 As the former Chief Justice explained, There was a geographical area [110 hectares, the total size of the DIFC] in which the Court [i.e., the DIFC Courts] had jurisdiction. The jurisdiction laws said, '[the Court] shall have jurisdiction over what happens in that territory and over persons who carry on business there.' You had to show that events took place there, a contract was formed there, or the defendant was registered there. ${ }^{192}$

The current Chief Justice used similar language in describing the earliest efforts to create the DIFC Courts: "you create a little island, a geographical island, and say that little geographical island will have autonomy and there's a carve-out of jurisdiction.",193 The Chief Justices' descriptions adhere to common law notions of territorial jurisdiction, that is, the power of a court over the events and persons within a particular geographic territory. Under the liberal rules of DIFC law (e.g., foreign investors can establish a company with one hundred percent foreign ownership), companies were encouraged to make the DIFC the place of their incorporation. This provided the DIFC Courts with a pool of potential parties, and yet there were limits to such a caseload.

The DIFC Courts' approach to its jurisdiction changed in 2011 from a geographic one to an elective one. ${ }^{194}$ The first indicator of change was the case Corinth Pipeworks

\footnotetext{
${ }^{187}$ See Dubai Law No. 12 of 2004, as amended, available at https://www.difc.ae/files/7014/5510/4276/Dubai_Law_No._12_of_2004_as_amended_English.pdf.

${ }^{188}$ Interview, Oxford, May 11, 2018.

189 Jonathan M. Miller, A Typology of Legal Transplants: Using Sociology, Legal History and the Argentine Example to Explain the Transplant Process, 51 AM. J. COMP. L. 839, 849-50, 854-55 (2003).

${ }^{190}$ See Palan et al. supra note 18 at 126-28.

${ }^{191}$ Interview, Oxford, June 13, 2018.

${ }^{192}$ Id.

${ }^{193}$ Interview, Oxford, May 11, 2018.

${ }^{194}$ Note that the Commercial Court also privileges elective jurisdiction.
} 
SA v. Barclays Bank PLC (hereinafter "Corinth"). ${ }^{195}$ As told to me by the first Chief Justice, the case concerned a Greek company, the claimant, which sold steel pipes to a buyer based in Jebel Ali, Dubai. ${ }^{196}$ The cause of action derived from an allegedly false statement made by an employee of the Jebel Ali branch of Barclays Bank where the buyer had an account. The claimant filed claims for damages against the respondent in the DIFC's Court of First Instance. The issue was whether the DIFC Courts had jurisdiction since Jebel Ali is in Dubai but outside the DIFC. The Deputy Chief Justice found that the Court of First Instance did not have jurisdiction and rejected the claimant's argument that the bank branch qualified as a "Centre's Establishment within the words of Article 5(A)(1)(a) of Law No. 12."197 On appeal, the Chief Justice reversed the decision, finding that the term "Centre Establishment" referred to the respondent as a single legal entity and not just to its DIFC branch. ${ }^{198}$ The decision had the effect of expanding the DIFC Court's jurisdiction over overseas parent companies that have a subsidiary in the DIFC. ${ }^{199}$

The Corinth decision was reinforced by a change in the legislative basis of the DIFC Courts' jurisdiction. Law No. 16 of 2011 provided that the Court of First Instance would have exclusive jurisdiction to hear and determine "any civil or commercial claims or actions where the parties agree in writing to file such claim or action with it." ${ }^{200}$ By allowing parties to elect for the DIFC Courts to obtain jurisdiction over their matter, the DIFC Courts greatly expanded the potential range of its users. Parties would not need to have a nexus with the DIFC Courts, and could be based in any jurisdiction. Similarly, the issue at dispute would not need to arise out of commercial activities located in the DIFC. As a result, in the years following these changes to elective jurisdiction, the DIFC Court's docket expanded. By 2015 and 2016, the Court of First Instance and Court of Appeal heard a total of 108 cases. $^{201}$

The third phase of its jurisdiction is "conduit jurisdiction." Although interpretations of conduit jurisdiction differ, the general idea is that the DIFC Courts, by recognizing foreign judgments and, in so doing, converting them into "judgments" that can be, in turn, recognized and enforced by the onshore Dubai courts, serve as "conduits" for resolving international commercial disputes. ${ }^{202}$ To understand how conduit

\footnotetext{
195 [2011] DIFC CA 002, https://www.difccourts.ae/2011/01/22/ca-0022011-corinth-pipeworks-sa-vbarclays-bank-plc/ (last visited Oct. 22, 2018).

${ }^{196}$ Interview, June 13, 2018.

${ }^{197}$ See supra note 187, art. 5 (A)(1)(a) ("The Court of First Instance shall have exclusive jurisdiction to hear and determine civil or commercial claims and actions to which the DIFC or any DIFC Body, DIFC Establishment or Licensed DIFC Establishment is a party").

${ }^{198}$ See Corinth supra note 195 (holding, "That is the natural and legal consequence of operating a branch or division of a bank, viz. that there is no separation of entity between an unincorporated branch of a foreign bank and the foreign bank itself').

${ }^{199}$ But see id. (asserting that the "floodgates" problem of too much litigation arising out of such expanded jurisdiction is limited by the forum non conveniens doctrine).

${ }^{200}$ Dubai Law No. 16, art. 5 (A)(2).

${ }^{201}$ See KRISHNAN, supra note 185.

${ }^{202}$ See DIFC Courts Enforcement Guide 2018 13, available at http://issuu.com/difccourts/docs/enforcement_guide_combined_single_?e=29076707/61750336 (providing claimants with the right to seek recognition and enforcement of foreign judgments in the DIFC Courts knowing that the defendants have no assets within the DIFC or other grounds for recognition in order to have access to the reciprocal enforcement mechanisms provided by article 7 of the Judicial Authority Law (Dubai Law No. 12 of 2004, as amended by Dubai Law No. 16 of 2011)). See also DNB
} 
jurisdiction works, it is important to first consider the question of the enforceability of DIFC Court judgments. Just as the DIFC Courts have been innovative in terms of jurisdiction, so, too, have they been entrepreneurial in terms of enforcement. As a baseline, DIFC Court decisions are fully enforceable within the DIFC. ${ }^{203}$ Beyond the DIFC, to enforce a DIFC Court decision within Dubai, the prevailing party must apply for an "execution letter" from the DIFC Courts, ${ }^{204}$ which is then submitted to the relevant onshore Dubai court for approval. As I explain below, this process is problematic given the jurisdictional turf-war between the DIFC Courts and onshore courts. ${ }^{205} \mathrm{Next}$, beyond Dubai, but within the UAE, a claimant may rely on Dubai Law No. $16^{206}$ that provides for automatic mutual enforcement of decisions issued by courts within the UAE. Beyond the UAE, a claimant must rely on a relevant treaty for mutual recognition and enforcement that the UAE has with the country of the foreign court in question. The UAE is party to a number of multilateral ${ }^{207}$ and bilateral agreements ${ }^{208}$ for reciprocal recognition and enforcement of foreign judgments. In the absence of a treaty, in the event that a claimant seeks enforcement of a DIFC Court judgment in another common law jurisdiction, then common law rules apply. These common law rules adopt a proenforcement approach based on the doctrine of obligation ${ }^{209}$ without requiring reciprocity ${ }^{210}$ or comity. ${ }^{211}$

The enforcement of DIFC Courts' own decisions (e.g., ratified judgments of foreign courts) is, then, the second step in conduit jurisdiction, the initial step being the DIFC Courts' capacity to recognize foreign judgments ${ }^{212}$ and arbitral awards. ${ }^{213}$ While the DIFC Courts' jurisdiction and enforcement powers are expansive, they are also fragile. Notwithstanding this architecture of rules for enforcement of DIFC Court judgments, the DIFC Courts' record of having their judgments enforced outside the DIFC

Bank ASA v. Gulf Eyadah Corp. \& Gulf Navigation Holding PJSC, [2015] DIFC CA 007 (holding that creditors can enforce their foreign judgments in Dubai via the conduit of the DIFC Courts if the debtors' assets are located in Dubai).

${ }^{203}$ See DIFC Courts Enforcement Guide 2018, supra note 202.

${ }^{204}$ Jayanth K. Krishnan \& Priya Purohit, A Common-Law Court in an Uncommon Environment: The DIFC Judiciary and Global Commercial Dispute Resolution, 25 AM. REV. INT'L ARB. 497, 506 (2014).

${ }^{205}$ But see DIFC Courts Strategic Plan 2016-2021 28, available at https://issuu.com/difccourts/docs/difc_courts_strategic_plan_2016-202 (citing the statistic that since 2008, "the DIFC Courts and Dubai Courts have seen more than a hundred of each other's decisions successfully enforced").

${ }^{206}$ See art. 7(2) (providing that when the subject matter is outside the DIFC, the judgment of the DIFC Courts will be executed by "the competent entity having jurisdiction outside the DIFC.")

${ }^{207}$ See 1983 Riyadh Convention on the Judicial Cooperation between the States of the Arab League; the 1995 Protocol on the Enforcement of Judgments, Letters Rogatory, and Judicial Notice issued by the Courts of the Member States of the Arab Gulf Co-operation; and the 1999 Gulf Cooperation Council (GCC) Convention for the Execution of Judgments, Delegations and Judicial Notifications.

${ }^{208}$ See Hassan Arab and Sara Koleilat-Aranjo, "Enforcement of Foreign Judgments," Getting the Deal Through (Oct. 2017), https://gettingthedealthrough.com/area/46/jurisdiction/33/enforcement-foreignjudgments-united-arab-emirates/ (providing a list of all such treaties).

${ }^{209}$ Schisbsby v. Westenholz, (1870) L.R. 6 Q.B. 155.

${ }^{210}$ Adams v. Cape Indus. PLC, (1990) ch. 433.

${ }^{211}$ Hilton v. Guyot, 159 U.S. 113 (1895).

${ }^{212}$ See Judicial Authority Law, art. 7(6); DIFC Court Law, art. 24(1)(1).

${ }^{213}$ The UAE ratified the NY Convention in 2006. See also Meydan Grp. LL v. Banyan Tree Corporate Pte Ltd, [2014] DIFC CA 005 (providing that the DIFC Courts have jurisdiction to recognize a foreign arbitral award outside the DIFC even in the even that the issue of dispute has no nexus with the DIFC). 
is not strong. According to one study, as of 2014, no Emirati court outside Dubai had enforced a DIFC judgment due to "lack of faith." 214 Internationally, DIFC Court judgments have been enforced by the United Kingdom and Australia. ${ }^{215}$ To complement its court procedures, the DIFC has also established the DIFC-LCIA Arbitration Centre, a joint venture with the LCIA, based in the City, which handles commercial arbitration matters.

To shore up conduit jurisdiction, the DIFC Courts have created a latticework of MOGs and MOUs with partner institutions throughout the world. These memoranda are not enforceable but they do show intent of courts and arbitration houses to enforce each other's decisions. The first MOG was signed with the London Commercial Court in 2013 . $^{216}$ Subsequently, the DIFC Courts have signed nine MOGs with courts throughout the world. ${ }^{217}$ Additionally, over the last decade, the DIFC Courts have signed eleven "collaboration MOUs" with courts within the UAE and the greater GCC. ${ }^{218}$ Despite the efforts, the efficacy of the soft law instruments is in doubt. One DIFC Courts insider remarked that the MOUs are "a brilliant concept that doesn't amount to much." ${ }^{219}$ Still, there is at least one precedent for its use: in 2014, an Australian court affirmed and enforced a decision by the Court of First Instance consistent with the MOG between it and the DIFC Courts for the reason that the respondent's assets were based in Australia. $^{220}$

Typical of current trends in the business models of NLHs, China has emerged as a prospective market for DIFC Courts' legal services. ${ }^{221}$ In 2016, the DIFC Courts were the first commercial court to sign an MOU with a court of the PRC, specifically, the

\footnotetext{
214 See Krishnan \& Purohit, supra note 204, at 509.

${ }^{215}$ DIFC Courts Enforcement Guide 2017 25, available at http://issuu.com/difccourts/docs/enforcement_guide_e5_2017?e=29076707/48883438.

${ }^{216}$ See Memorandum of Understanding on Strengthening Judicial Exchange and Cooperation between Commercial Court, Queen's Bench Division, England and Wales and Dubai International Financial Centre Courts (signed Jan. 23, 2013).

${ }^{217}$ These include the Supreme Court of New South Wales (signed Sept. 9, 2013), the Federal Court of Australia (signed Mar. 28, 2014), the Commercial \& Admiralty Division of the High Court of Kenya (signed Nov. 27, 2014), the Supreme Court of Singapore (signed Jan. 19, 2015), the District Court for the Southern District of New York (signed Mar. 22, 2015), the Supreme Court of the Republic of Kazakhstan (signed Aug. 28, 2015), and the National Court Administration of the Supreme Court of Korea (signed Nov. 4, 2015). In addition, the DIFC Courts has established an "MOU on References of Questions of Law" with the Supreme Court of Singapore (signed Jan. 19, 2015).

218 These include a "collaboration MOU" with the Dubai courts (July 16, 2009); a "protocol of jurisdiction" with the Dubai Courts (May 1, 2009) for "due enforcement of the judgments rendered by the other Party"; a second such "protocol of jurisdiction" with the Dubai Courts, (Dec. 7, 2009) for "[f]ollow[ing] the concerning laws and regulations as for the jurisdiction issue between DIFC Courts and Dubai Courts"; and "collaboration MOUs" with: Notary public Department of the Dubai Courts, Ministry of Justice of Jordan, UAE Ministry of Justice, Dubai Judicial Institute, and Ra Al Khaimah Courts; and a "service MOU" with the international Cooperation Department of the UAE Ministry of Justice.

${ }^{219}$ Interview, Oxford, June 13, 2018.

${ }^{220}$ See Graciela Ltd. v. Giacobbe [2014] DIFC CFI 027 (finding for the claimant in a wrongful interference in property suit).

${ }^{221}$ See Michael Fahy, Courting the Chinese Legal System a Priority for DIFC, THE NATIONAL (Mar. 13, 2017), https:/www.thenational.ae/business/courting-the-chinese-legal-system-a-priority-for-difc1.14384 ? videoId=5604157226001.
} 
Shanghai High People's Court. ${ }^{222}$ In addition, the DIFC Courts' sole MOU with an arbitration institution is in China-namely, Hangzhou. ${ }^{223}$ UAE-China trade and investment is soaring, particularly given the geostrategic centrality of the UAE to the region. ${ }^{224}$ During Xi Jinping's visit to the UAE in July 2018, the UAE minister of the economy projected that UAE-China trade would grow to $\$ 58$ billion in 2018 , an increase of $8.4 \%$ from the previous year. ${ }^{225}$

While the DIFC Courts has been an innovator in expanding its jurisdiction through case law, on the enforcement end, and in accordance with the idea of bundling dispute resolution services, they have also introduced cross-institutional mechanisms. One example is a mechanism by which parties opting into the jurisdiction of the DIFC Courts can also refer their final judgments for enforcement through the DIFC-LCIA Arbitration Centre. ${ }^{26}$ The mechanism allows the DIFC-LCIA to convert judgments into arbitral awards that can then be enforceable abroad through the New York Convention. ${ }^{227}$ While the effects of incorporating more inclusive policies into the court's operations remains to be seen, the mechanism to convert a judgment into an arbitral award, much like the MOGs and MOUs, is mainly untested. As of 2017, no party had opted to use the mechanism, likely out of concern that other jurisdictions, at the enforcement stage, may not consider the conversion of the judgment into an arbitral award to be valid because nonpayment of a judgment may not be a genuine dispute capable of being referred to arbitration. $^{228}$

\footnotetext{
${ }^{222}$ Memorandum of Understanding on Strengthening Judicial Exchange and Cooperation between Shanghai High People's Court and Dubai International Financial Centre Courts (signed Oct. 26, 2016).

${ }^{223}$ Memorandum of Understanding for the Furtherance of Collaboration between the Hangzhou Arbitration Commission and the Dubai International Financial Centre's Dispute Resolution Authority (signed Oct. 27, 2017).

${ }^{224}$ Martin Jacques, The UAE Will Have Significance in China's Road Drive, GuLF NEws (Feb. 27, 2018), https://gulfnews.com/business/analysis/the-uae-will-have-significance-in-china-s-road-drive-1.2179874 (noting that given the location of its ports, the UAE is well-positioned to benefit from BRI-related trade). ${ }^{225}$ See Fareed Rahman, Al Mansouri: UAE-China Trade Could Reach $\$ 58$ billion This Year, GuLF NEwS (July 20, 2018), https://gulfnews.com/business/economy/al-mansouri-uae-china-trade-could-reach-58bthis-year-1.2254530.

${ }^{226}$ The DIFC-LCIA was established in 2008 as a joint venture between the DIFC and the LCIA. Following challenges to its jurisdictional reach, Dubai Law No. 7 of 2014 available at https://www.difc.ae/files/6914/5510/4274/Dubai_Law_No._7_of_2014_English.pdf was passed to establish the Dispute Resolution Authority which in turn governs the DIFC Arbitration Institute (DAI). The DAI entered into an agreement with the LCIA to relaunch the DIFC-LCIA in 2015. See DIFC-LCIA, Overview, http://www.difc-lcia.org/overview.aspx (last visited Oct. 22, 2018).

${ }^{227}$ DIFC Courts Practice Direction No. 2 of 2015 on Referral of Judgment Payment Disputes to Arbitration (Feb. 16, 2015), available at https://www.difccourts.ae/2015/02/16/difc-courts-practice-direction-no-22015-referral-judgment-payment-disputes-arbitration/ (stating that the parties may "further agree that any dispute arising out of or in connection with the non-payment of any money judgment given by the DIFC Courts may, at the option of the judgment creditor, be referred to arbitration under the Arbitration Rules of the DIFC-LCIA Arbitration Centre").

${ }^{228}$ Christopher Mainwaring-Taylor \& Yacine Francis, DIFC Courts Introduce Unique Mechanism to Convert DIFC Money Judgments into Arbitral Awards, ALLEN \& OVERY (Oct. 18, 2018), http://www.allenovery.com/publications/en-gb/lrrfs/middleeastandafrica/Pages/DIFC-Courts-introduceunique-mechanism-to-convert-DIFC-money-judgments-into-arbitral-awards-n.aspx. See also Dalma R. Demeter \& Kayleigh M. Smith, The Implications of International Commercial Courts on Arbitration, $33 \mathrm{~J}$. INTER'L ARB. (2016).
} 
Notwithstanding the Joint Tribunal and the lack of interest in some of its procedural innovations, the DIFC Courts have obtained relative success in attracting international parties to its venue. On the question of judicial independence, where governmental bodies have appeared before the DIFC Courts, principally the guise of the DIFC Authority, the principal governing body of the DIFC, the DIFC Courts have found in favor of the government. ${ }^{229}$ However, the DIFC Courts have also ruled against quasigovernment corporations, ${ }^{230}$ which in fact have sought to avoid the DIFC Courts. Further, the Dubai World Tribunal, established in 2009 to hear demands to liquidate the stateowned corporation, and which features DIFC Courts judges, has ruled against the state. While not conclusive, evidence suggests that it is possible for nondemocratic and hybrid states to build hubs that have credible dispute resolution mechanisms that may find against the host state.

\section{Astana}

Despite its limitations, the DIFC Courts model has been replicated elsewhere. It has inspired a duplicate in Kazakhstan: the AIFC Courts, announced in 2015 and officially opened on January $1,2018 .{ }^{231}$ Given its relative newness - as of the end of 2018, the AIFC Courts had not yet received a case - there is not much data available, but a few preliminary observations can be made. The AIFC Courts is even more artificial than the DIFC Courts given that lack of connection with the former British Empire and English common law. Nonetheless, the AIFC Courts law is based on English common law procedural rules, ${ }^{232}$ and led by the Chief Justice Woolf, the former Lord Chief Justice of England and Wales. The AIFC is itself a so-called "mid-shore" SEZ, and allows for the transplantation of exogenous rules.

The establishment of the AIFC Courts is born of the geopolitics of Inter-Asia. First, President Nazarbayev has sought to situate Kazakhstan as the commercial, infrastructural, and technological corridor between Europe and Asia. In 2014, in a bid to diversify the economy beyond oil dependency, President Nazarbayev announced the Nurly Zhol ("bright path") economic stimulus plan worth $\$ 9$ billion to promote infrastructure building for this purpose. ${ }^{233}$ The Nurly Zhol initiative, Kazakhstan's answer to the BRI, further coincides with the privatization of Samruk-Kazyna, a sovereign wealth fund that owns many of the country's core natural resource and utilities companies. ${ }^{234}$ The Kazakh Government does not want to list private companies outside of the country and so has built an exchange and sought to design a system of regulation to

\footnotetext{
${ }^{229}$ See Marwan Lutfi v. DIFC Authority, [2013] DIFC CA 003, https://www.difccourts.ae/2014/11/26/ca0032013-marwan-lutfi-v-dubai-international-financial-centre-authority/ (last visited Dec. 5, 2018); Hana Al Herz v. DIFC Authority, [2013] DIFC CA 004, https://www.difccourts.ae/2014/11/27/ca-0042014-hana-alherz-v-dubai-international-financial-centre-authority/ (last visited Dec. 5, 2018).

${ }^{230}$ See Meydan Group v. Banyan Tree, [2014] DIFC CA 005, https://www.difccourts.ae/2014/11/03/claimca-005-2014-meydan-group-llc-v-banyan-tree-corporate-pte-ltd/ (last visited Dec. 5, 2018).

${ }^{231}$ Interview by telephone with member of AIFC Courts, Aug. 3, 2018.

${ }^{232}$ See Constitutional Statute of the Republic of Kazakhstan on the Astana International Financial Centre, No. 438-V ZRK, Dec. 7, 2015, as amended Dec. 22, 2017, effective Jan. 9, 2018, art. 13 (providing the jurisdiction of the AIFC Courts), AIFC Court Regulations, Dec. 5, 2017 (explaining the constitution of the court, its management, composition, applicable law, etc.), and AIFC Court Rules 2018, available at http://aifc-court.kz/legislation (providing detailed provisions on all aspects of court procedure).

${ }^{233}$ AIFC Presentation, dated Jan. 17, 2017, on file with the author. ${ }^{234} \mathrm{Id}$.
} 
ensure that the wealth benefits the country. A second factor is China and the BRI. President Xi announced the BRI in Astana in 2013. Setting up a bespoke dispute resolution platform both protects Kazakh parties involved in BRI deals and potentially foreign parties who want to access the Chinese market. As of 2018, some 52 projects have been commenced in Kazakhstan under the BRI for a total value of \$24 billion. ${ }^{235}$ Third, at the level of big-man politics, President Nazarbayev is a close friend with the Sheikh, and NLHs have become something of a prized possession for autocratic leaders. Against this backdrop, the AIFC Courts are meant to provide an impartial and efficient forum for sophisticated cross-border transactions across Inter-Asia and in the Central Asian region, in particular.

The DIFC-AIFC relationship shows NLHs' self-replication. Experts from the DIFC Courts were directly involved as consultants on the design of the AIFC Courts, including through its Legal Advisory Council which has imported DIFC law to the AIFC with adjustments. Likewise, it is no coincidence that the DIFC Courts established an MOG with the Supreme Court of Kazakhstan the year that the AIFC Courts were established. $^{236}$ These institutional links show how the DIFC Courts (themselves modeled, in part, on Singapore) have been vital to the founding of the AIFC Courts. Given their geographic distance, the DIFC Courts and AIFC Courts are not direct competitors, but complement each other through a number of projects, including the mutual recognition and enforcement of each other's judgments.

\section{Shanghai and Shenzhen}

China has also emerged as a player in the field of international commercial dispute resolution by starting to build NLHs. Given the surge in Chinese outbound investment over the past decade, Chinese companies are increasingly encountering crossborder disputes, particularly in the areas of construction and project finance, the core transactional work of the BRI. Much of China's post-1978 commercial law was written with China as a recipient of FDI in mind, but now that China is a promoter of economic globalization, legal reform is afoot. As Chinese corporations increasingly encounter legal disputes in the course of their investment abroad, part of this reform includes modernizing conflict of laws rules ${ }^{237}$ and dispute resolution mechanisms. While Chinese corporations will continue to use Hong Kong, Singapore, and other hubs, the Chinese Government is interested in onshoring some of the fundamentals of the hubs.

The idea of the legal hub finds most traction at the subnational level, specifically, municipalities. ${ }^{238}$ In conjunction with the central government, municipal governments have sought to create jurisdictional carve-outs, namely SEZs, FTZs, and cooperation districts that are beginning to look like nascent hubs. Competition between regions and

\footnotetext{
${ }^{235} I d$.

${ }^{236}$ See Memorandum of Guidance as to Enforcement between Supreme Court of the Republic of Kazakhstan and DIFC Courts, Aug. 8, 2015.

${ }^{237}$ See e.g., Qingkun Xu, The Codification of Conflicts Law in China: A Long Way to Go, 65 AM. J. COMP. L. 919 (2018).

${ }^{238}$ One of the hallmarks of the reform period has been the delegation of decision making to subnational authorities. See, e.g., Meg Rithmire, China's 'New Regionalism': Subnational Analysis in Chinese Political Economy, 66 World Politics 165 (2014); Jun Zhang \& Jamie Peck, Variegated Capitalism, Chinese Style: Regional Models, Multi-Scalar Constructions, 50 REgIONAL STUD. 52 (2016); JAE Ho CHUNG, CitiEs In CHINA: RECIPES FOR ECONOMIC DEVELOPMENT IN THE REFORM ERA (1999).
} 
cities is a particular driver of these exceptional zones. Shanghai has been competing with Hong Kong since the 1990s, and Shenzhen, established as a SEZ in 1980, has over the past three decades achieved record rates of urbanization. China has entered a stage in its growth, specifically that of its coastal cities, where it may begin to cut out the middleman, the fear of the Hong Kong-based corporate lawyer, mentioned above. ${ }^{239}$ China has been studying Singapore's Maxwell Chambers and developments in Hong Kong. Concurrently, jurisdictions such as the DIFC Courts have also been studying China's advancements in lawtech. While China is already part of the emergent landscape, it faces difficulties in constructing and promoting its NLHs. Obstacles to Chinese NLHs' legitimacy and practicality include uneven enforcement, Chinese language, and an authoritarian government.

China's embryonic NLHs_-Shanghai and Shenzhen — are not as organic as Singapore and not as artificial as Dubai. They have each sought to build legal infrastructures, legal services, and legal cultures. They have done so through jurisdictional carve-outs, even featuring traces of Anglophone common law. Shanghai featured "mixed courts" in the mid-nineteenth century, which applied English common law to criminal and civil cases. ${ }^{240}$ While some of contemporary PRC reformers would be aghast at the suggestion that Shanghai's financial success could be traced to its historical incorporation (however, partial) into the English common law sphere, nonetheless, at least one leading PRC legal scholar has proposed that Shanghai found a "special law district" (tefaqu) that would apply English common law. ${ }^{241}$ That proposal was directed at designing rules for the Shanghai Pilot Free Trade Zone (hereinafter "the Zone"), an agglomeration of existing FTZs, established in 2013, to "form a legal framework for investment and trade within the zone." ${ }^{, 42}$ While the common law proposal failed, the Zone has tailored existing PRC law on customs and trade. ${ }^{243}$

Shenzhen never served as a British possession, but has selectively borrowed elements of the English common law tradition through Hong Kong in an effort to internationalize its legal services. In Shenzhen, the PRC Governments has created, in effect, an exceptional zone within an exceptional zone with the Qianhai Shenzhen-Hong Kong Modern Services Cooperative District (hereinafter "the District"), based in the SEZ. The District, founded in 2010, and comprised of eighteen square miles, is a pilot project to incubate the service industries, including finance and law, between Guangdong and Hong Kong, exemplifying some of the spillover of agglomeration, one that draws on the established hub of Hong Kong. ${ }^{244}$ Specifically, the District has established special

\footnotetext{
239 See supra text accompanying note 151.

${ }^{240}$ PÄr KRISTOFFER CASSEL, GROUNDS OF JUDGMENT: EXTRATERRITORIALITY AND IMPERIAL POWER IN NiNETEENTH-CENTURY CHINA AND JAPAN 67-73 (2012).

${ }^{241} \mathrm{Ji}$ Weidong (季卫东), Zhongguo (Shanghai) ziyou maoyi shiyanqu falü wenti yanjiu (中国（上海）自 由贸易试验区问题研究) [Legal Problem Research on the China (Shanghai) Free Trade Zone], 1 DONGFANG FAXUE (东方法学) [EASTERN LEGAL STUDIES] 86 (2014).

${ }^{242}$ China (Shanghai) Pilot Free Trade Zone, Introduction, http://en.china-shftz.gov.cn/AboutFTZ/Introduction/ (last visited Oct. 22, 2018).

${ }^{243}$ Regulations of the China (Shanghai) Pilot Free Trade Zone, adopted at the 14th Session of the Standing Committee of the 14th Shanghai Municipal People's Congress of Shanghai on July 25, 2014, http://en.china-shftz.gov.cn/Government-affairs/Laws/General/319.shtml.

${ }^{244}$ Guangdong Ziyou Maoyi Shiyanqu Shenzhen Qianhai Shekou Pianqu Qianhai Shen-Gang Xiandai Fuwuye Hezuoqu (广东自由贸易试验区深圳前海蛇口片区前海深港现代服务业合作区), Qianhai
} 
courts to accept foreign-related matters. These include the Shenzhen Qianhai Cooperative District People's Court, an experimental court that has introduced many features familiar outside of China: a jurisdiction that includes foreign-related suits, jurors or "lay assessors" of Hong Kong nationality, and English as the working language of judges. ${ }^{245}$ The officer from the DIFC Courts, who visited the court told me that its rules, such as cost-shifting to incentivize settlement, mimic those of common law courts. ${ }^{246}$ In addition, in 2018, the District founded one of China's two "international commercial courts" (guoji shangshi fating). Established under the SPC, the international commercial court is deemed to be a "one-stop shop" for foreign-related commercial disputes, including mediation, arbitration, and litigation. ${ }^{247}$ Further demonstrating how NLHs, like Sassen's global cities, collapse global processes into manageable sites, the international commercial court features an "international commercial expert committee" comprised of twelve Chinese and twenty non-Chinese legal professionals who provide expertise, to supplement that of the English-speaking judges, on substantive and procedural matters. ${ }^{248}$

Both the Zone and the District are sites of bundled dispute resolution venues. In parallel with Shenzhen's specialized courts, Shanghai established a financial court in 2018 under the Shanghai Intermediate People's Court. According to Zhou Qiang, President of the SPC, the financial court draws from examples in the United States, United Kingdom, UAE, and Kazakhstan, and will be vital to establish the "Shanghai international financial center." 249 Servicing international arbitration institutions and courts is one of the highest concentrations of lawyers in China, including foreign and Chinese. $^{250}$ The Zone includes the Shanghai International Arbitration Center (SHIAC), established in 1988. SHIAC began receiving international cases (defined as both parties are non-Chinese) in 2000 and receives about ten to fifteen such cases per year. ${ }^{251}$ In 2017 ,

guanliju (前海管理局) [Qianhai Management Bureau], http:/www.szqh.gov.cn/ljqh/qhji515/hzqjs515/ (last visited Oct. 22, 2018).

${ }^{245}$ Shenzhen Qianhai Hezuoqu Renmin Fayuan (深圳前海合作区人民法院), Jiben qingkuang (基本情况) [Basic Situation], http://www.szqhcourt.gov.cn/fyjj/fygk.aspx?cls=1 (last visited Oct. 22, 2018).

${ }^{246}$ Interview, London, November 6, 2017, and Oxford, January 11, 2018. Subsequent inquiries with the Shenzhen Qianhai Cooperative District People's Court suggest that the court's procedures for court fees and lawyers' fees approximate those of other PRC courts. That is, the plaintiff pays the court fees in advance when filing a case and if she wins, the court may return the fees and the defendant pays. For the lawyers' fees, the loser may pay the other party's costs. Whereas in all PRC courts, the judge has discretion on the payment of court and lawyers' fees, the difference with the Shenzhen Qianhai Cooperative District People's Court may be that certain of its judges exercise more discretion than the norm.

${ }^{247}$ Zuigao remin fayuan guanyu sheli guoji shangshi fating ruogan wenti (最高人民法院关于设立国际商 事法庭若干问题的规定) [Regulations on Certain Issues in Establishing an International Commercial Court], passed by the SPC Judiciary Committee on June 25, 2018 and effective July 1, 2018 [hereinafter Regulations], art. 11.

${ }^{248} I d$.

${ }^{249}$ National People's Congress, Guanyu zai Shanghai sheli jinrong fayuan de jueding (cao'an) (关于在上 海设立金融法院的决定 (草案) 的说明) [Explanation of the “Decision on the Establishment of a Financial Court in Shanghai (Draft)"] (Apr. 25, 2018), http://www.npc.gov.cn/npc/xinwen/201804/27/content 2053989.htm.

${ }^{250}$ See Foreign \& Commonwealth Office, List of Lawyers in China, https://assets.publishing.service.gov.uk/government/uploads/system/uploads/attachment_data/file/724871/L ist_of_lawyers_in_China_12072018.pdf (last visited Oct. 22, 2018).

${ }^{251}$ Interview with SHIAC, Shenzhen, Apr. 20, 2018. 
they received 740 cases, about twenty percent of which were foreign-related. ${ }^{252}$ The average case was worth twenty million RMB (US\$2.89 million). ${ }^{253}$ In reference to the BRI, of the seventy-four countries represented among their arbitrators, there are thirty-six BRI countries. As with other hubs, they promote hubs elsewhere and have established the China-Africa Joint Arbitration Centre in Johannesburg, deemed to serve as one of the dispute resolution centers for China's presence in Africa.

The District includes the Shenzhen Court of International Arbitration (SCIA) which, being founded in 1983, predates the District. On December 1, 2016, the SCIA became the first Chinese arbitration institution to issue rules based on the UNCITRAL Rules demonstrating its commitment to international standards. ${ }^{254}$ In terms of legal service providers, regarding the lawyers who use the SCIA and the bespoke courts, the District has some thirty law firms and seven "joint ventures" between mainland and Hong Kong law firms; the District is growing its base for providing legal services, many of them practicing trade, maritime, and investment law. ${ }^{255}$ Also, in 2014, the think tank Benchmark Chambers International, one of the three "foreign law verification centers" in the country, was founded to provide expertise on foreign law questions. ${ }^{256}$

The PRC Government has sought to address obstacles to foreign parties' use of Chinese venues and PRC law, specifically, poor legal implementation, language, and regime legitimacy, by constructing dispute resolution institutions that borrow from best practices elsewhere (sometimes, common law jurisdictions), developing bilingual talent, and promoting institutions "independent" of government intrusion. Further, the Chinese are increasingly taking their place as the new transnational elite, including Chinese corporate lawyers and arbitrators. During a lecture given by Michael Hwang, the seventyfive-year-old Chief Justice of the DIFC Courts, he praised Gao Xiaoli, Judge of the SPC's Fourth Civil Division and of the international commercial court, whom he had met with several times in China, Dubai, and in New York City, as a leader in judicial reform, and someone who is "not yet 40" (she is forty-five). ${ }^{257}$ It is experts like Gao Xiaoli who are connecting dispute resolution in China with circles outside of China, and facilitating the internationalization of Chinese legal practices.

At the same time, while China has become a leader in lawtech with machine learning and $\mathrm{AI}$ that address such concerns as language, ${ }^{258}$ it is harder for the government to sideline the negative effects of authoritarian revival under Xi. The expansion of the party-state under Xi has marginalized foreign actors, including lawyers. Whereas many jurisdictions like Singapore and Hong Kong have created uniform disciplinary rules for

\footnotetext{
${ }^{252} \mathrm{Id}$.

${ }^{253} \mathrm{Id}$

${ }^{254}$ Shenzhen Court of International Arbitration, Arbitration Rules (effective Dec. 1, 2016), http://res.cloudinary.com/lbresearch/image/upload/v1477646738/scia_rules_2016_en_289116_1025.pdf. ${ }^{255}$ Qianhai Shen-Gang Xiandai Fuwuye Hezuoqu (片区前海深港现代服务业合作区),Yuegang'ao da wan qu qingnian fazhan falü luntan zai Shenzhen juxing (粤港澳大湾区青年发展法律论坛在深圳举行) [Guangdong, Hong Kong, Macau and Dawan District Youth Development Forum was held in Shenzhen], http://www.szqh.gov.cn/ljqh/fzqh/fzjxs/201809/t20180910_14075548.htm (last visited Oct. 22, 2018).

${ }^{256}$ Interview, Shenzhen, Mar. 28, 2018.

${ }^{257}$ Chief Justice Dr. Michael Hwang, "Legal Challenges Arising from the Belt and Road Initiative: Views from the Dubai International Financial Centre Courts," Oxford China Centre, May 11, 2018.

${ }^{258}$ Artificial Lawyer, The Rise of China's Advanced Legal Tech Scene (Mar. 29, 2017), https:/www.artificiallawyer.com/2017/03/29/the-rise-of-chinas-advanced-legal-tech-scene/.
} 
lawyers (native and nonnative), foreign lawyers continue to face restrictions in China (e.g., advising on PRC law, litigating in PRC courts, etc.) that create an uneven playing field and inhibit some of the globalizing effects hubs experience elsewhere. The Chinese hubs are in some ways even more demand driven than Dubai or Astana, yet their growth may be frustrated by the PRC Government's monopoly over the legal industry.

To summarize, a theory of NLHs is not complete without considering hubs on a continuum from organic to artificial and as tiered within that continuum. Table $3^{259}$ provides a snapshot of some of the main indicators of the legal industry in each hub. I include London's numbers as reference. In the part that follows, I examine the interaction between hubs and their host states.

Insert Table 3 here.

\section{NLH-Host State Interactions}

NLHs and their host states are constantly interacting with each, as hubs and states respond to the uncertainty of the international political economy. Certain NLHs, in particular those that are more or less organic, like Hong Kong and Singapore, have been relatively successful in facilitating international commercial transactions and benefitting the city-state. Evidence of their success comes in the form of the high rankings of Hong Kong and Singapore as venues for international arbitration and the UNCITRAL's nod to Singapore as a mediation center in the eponymous mediation enforcement regime. For many of the artificial hubs, because they are relatively new, they do not yet have a proven track record. The DIFC Courts, the most established of the newer hubs, has nonetheless

\footnotetext{
${ }^{259}$ Interviews with on-site experts in London (Nov. 6, 2017, Feb. 5, 2018, June 20, 2018, July 3, 2018), Hong Kong (Aug. 2-4, 2017, Mar. 27-28, 2018), Singapore (Aug. 8-17, 2018), and Shenzhen (Mar. 28, 2018); Dubai Chamber, ANNuAl RePORT 201771 (2018); PorTland, COMMERCial COURTS REPORT 1 2018 (2018); THE LaW Society, TRENDS In THE Solicitors' Profession ANNUAl Statistics Report 2017 11, 25 (2018); THE LONDON COURT OF INTERNATIONAL ARBITRATION, 2017 CASEWORK REPORT 4 (2018); DIFC Courts, Judgments and Orders, https://www.difccourts.ae/judgments-and-orders/ (last visited Dec. 5, 2018); Guo Ruichuan [郭锐川], Shenzhen lüshi renshu yijing chaoguo 1.2 wan ming (深圳律师人 数已经超过 1.2 万名) [The Number of Lawyers in Shenzhen Has Reached 12,000], AO YI WANG (奥一网) [One Profound Net] (Apr. 2, 2018), http://3g.oeeee.com/m.php?s=/m/mshow/ctime/1522640314/id/594829/type/html/mtype/1; Hong Kong International Arbitration Centre, 2017 Statistics, http://www.hkiac.org/about-us/statistics (last visited Dec. 5, 2018); Shanghai Shi Renmin Zhengfu [上海市人民政府], Shanghai lüshi zongshu yu 2 wanren (上海律 师总数逾 2 万人) [The Number of Lawyers in Shanghai Exceeds 20,000], Shanghai Shi Renmin Zhengfu ( 上海市人民政府) [Shanghai Municipal People's Government] (Mar. 20, 2017),

http://www.shanghai.gov.cn/nw2/nw2314/nw2315/nw4411/u21aw1215932.html; Singapore International Arbitration Centre, Annual Report 201713 (2018),

http://www.siac.org.sg/images/stories/articles/annual_report/SIAC_Annual_Report_2017.pdf; Ministry of Law, Legal Services Regulatory Authority E-Services (Oct. 19, 2019),

https://www.mlaw.gov.sg/eservices/lsra/search-lawyer-or-law-firm/; E-mail correspondence with the DIFC Dispute Resolution Authority (July 9, 2018); E-mail correspondence with the DIFC-AIFC (Dec. 6, 2018); Government of Dubai, Legal Consultancy Firms List (Oct. 19, 2018), https://lps.legal.dubai.gov.ae/Portal/DirectorySearch?isrtl=false\#; City of London Law Society Who We Are (Oct. 19, 2018), http://www.citysolicitors.org.uk/index.php?option=com_content\&view=article\&id=73\&Itemid=468; Law Firms in Kazakhstan, Nov. 26, 2018 (on file with the author); see THE LAW SOCIETY OF HONG KonG, supra note 126; Krishnan \& Purohit, supra note 204, at 500.
} 
experienced a six-fold increase in its caseload between the years 2008 and $2017 .{ }^{260}$ Hubs have done so through transnational law, specifically, by tailoring conflict of law rules, interpreting inter-corporate agreements, issuing arbitral awards and mediated settlements, and developing a body of common law rules pertaining to corporate transactions (as in the case of the DIFC Courts).

Beyond this general success in attracting international parties to their respective venues and raising the profile of their host states, theoretically, hubs can have positive spillover effects on the host state. These effects include professionalizing onshore dispute resolution experts through judicial exchange and training, sharing resources and technology, and linking domestic institutions with foreign counterparts. However, for the most part, such spillover is rare. Hubs' parties are elite multinational corporations; the nature of the disputes hubs handle is complex commercial transactions. Consequently, the relevant law and doctrines invoked may differ from those cited in nonhub host state institutions. Consequently, the specialization of the dispute resolution experts in hubs may differ from those of nonhub experts.

Perhaps the ideal case to test the potential for hubs to positively impact the host state is China. ${ }^{261}$ The Shanghai judiciary, for example, has made a major push to internationalize, including the Shanghai High People's Court's application of foreign law in ten cases since 2014 and Shanghai courts' processing of some 2,600 cases involving BRI states since 2013. ${ }^{262}$ Moreover, Shanghai courts are, like the Shenzhen special courts, adopting bilingual Chinese-English policies, at least in how they present themselves to potential parties. ${ }^{263}$ These are clear indications that Shanghai authorities want their hub to be accessible to foreign parties. In the case of Shanghai, authorities are building bespoke institutions such as those in the Zone while also reforming and internationalizing institutions in the broader municipality; nonetheless, it remains to be seen whether these reforms can impact dispute resolution beyond the hub in, for instance, neighboring Jiangsu or Anhui provinces.

While evidence of positive spillover seems scarce, nearly all hubs have, in recent years, faced opposition from their host state. While pushback is caused by different reasons and assumes different forms, the common denominator is the relative success of many NLHs and the perception of actors in host states that exceptional zones may eclipse their host state. NLHs' image-work, which promotes their success, may exacerbate these

\footnotetext{
${ }^{260}$ DIFC Courts Annual Review 2009 28, available at https:/www.difccourts.ae/wpcontent/uploads/2017/10/DIFCC_annualreview2009.pdf (showing that the number of cases received by the Court of First Instance in 2008 was 9); DIFC Courts Annual Review 2017 20, available at http://issuu.com/difccourts/docs/difc-annualreview2017 jpgs?e=29076707/58783045 (showing the number of cases received by the Court of First Instance in 2017 was 54).

${ }^{261}$ Among the organic hubs (Hong Kong and Singapore), it is difficult to differentiate the NLH proper from the host state itself given they are city-states. It is possible to make such distinctions with the DIFC and AIFC given that they are circumscribed territories although, as I show, the impact of the former has been perceived as larger negative and the latter is too new to make assessments.

${ }^{262}$ Zhou Wenting, Shanghai Courts Apply More Foreign Laws in International Cases, Supreme People's Court of the PRC (Nov. 12, 2018), available at http://english.court.gov.cn/2018-

11/12/content_37243793.htm.

${ }^{263} I d$. (describing how the West Hongqiao Tribunal has adopted an English-language website).
} 
perceptions. In other words, hubs may create unintended negative externalities on host states, a problem I explore in detail below. ${ }^{264}$

Moving from how hubs can affect host states to how host states (and their law and policy) impact hubs, the determining factor for the viability of a NLH-whether organic or artificial - is state support. State support refers to the allocation of resources (budgetary and symbolic) in hub creation and promotion. The state may change its policy toward the hub; this can work either to the hub's benefit or detriment. State support may take the form of a policy for hub creation that did not previously exist; in other words, an organic hub may become "more artificial" through the building of an infrastructural platform for the hub. Alternately, a state may withdraw its support for a hub if offshore courts are seen to unfairly compete with onshore courts, proving that even nondemocratic states comprise plural political interests. Another possibility is that the state may undergo regime change, which may affect support for the hub. For these reasons, in positivist terms, state support is a kind of independent variable for the success of a NLH. These intrastate tensions may be exacerbated by globalization's slowdown.

\section{A. Dubai and Astana}

The DIFC Courts have experienced pushback from Dubai onshore courts against their expanded jurisdiction, and specifically the idea of "conduit jurisdiction." When the DIFC Courts were established, its unofficial motto, in reference to the onshore courts, was "now you can choose." 265 There was an element of cultural hubris in such a frame. All of the qualities that have made the DIFC Courts stand out as a venue - its cosmopolitan bench, drive for technology, and global visibility, in short, its elitism - are fodder for discontent. Judges, too, it seems can feel "left out" by globalization.

This sentiment has since comes back to haunt the DIFC Courts in the form of the Joint Tribunal of the Dubai Courts and the DIFC Courts (hereinafter "Joint Tribunal"), ${ }^{266}$ established in 2016. The Joint Tribunal is comprised of four judges from the onshore Dubai courts and three from the DIFC Courts in order to settle jurisdictional conflicts between the courts. In cases to date, the Joint Tribunal has curtailed the DIFC Courts' jurisdiction to enforce Dubai-seated arbitration awards, ${ }^{267}$ although the Joint Tribunal's view of the DIFC Courts' jurisdiction over foreign awards and judgments is less clear. ${ }^{268}$ The significance of the Joint Tribunal is that it represents some of the forces that have been labeled as deglobalization, specifically, local protectionism against the perceived intrusion of foreign-inspired institutions and transnational elites. Emirati officials, judges,

\footnotetext{
${ }^{264}$ See Neuman, supra note 17, at 1197 (arguing that anomalous zones have "subversive potential" beyond their designated boundaries).

${ }^{265}$ Interview, Oxford, July 19, 2018.

${ }^{266}$ Established pursuant to Decree No. (19) of 2016, issued June 9, 2016.

${ }^{267}$ Daman Real Capital Partners Co. LLC v. Oger Dubai LLC (Cassation No. 1 of 2016) (holding that onshore Dubai Courts are the competent court to determine the validity of an arbitral award seated in onshore Dubai); Dubai Water Front LLC v. Chenshan Liu (Cassation No. 2 of 2016) (finding that the onshore Dubai Courts are the competent court to determine the validity of an arbitral award conferred by the Dubai International Arbitration Centre against an onshore company with no presence in the DIFC).

${ }^{268}$ In a line of cases, the Joint Tribunal has neglected to opine on the DIFC Courts' jurisdiction over foreign awards and judgments when there is no direct conflict between the onshore Dubai Courts and the DIFC Courts in terms of parallel proceedings. See, e.g., Marine Logistics Sols. LLC and another v. Wadi Woraya LLC and others (Cassation No. 3 of 2016); Gulf Navigation Holding PJSC v DNB Bank ASA (Cassation No. 5 of 2016); Al Zaitoon, Olive Grp. v. Al Delma (Cassation No. 2 of 2017).
} 
and members of the legal industry who are not part of the NLH of the DIFC Courts have sufficient political clout to curb its operations. While the DIFC Courts are responding to this threat by adopting a more inclusive approach to its operations, ${ }^{269}$ it remains to be seen whether such efforts are sufficient to secure its status as a legal hub.

The AIFC Courts are learning from the example of the DIFC Courts. The AIFC Courts are not a complete clone of the DIFC Courts. Whereas the DIFC Courts are considered on par with the district courts of Dubai, the AIFC Courts are not part of the judicial system of Kazakhstan. ${ }^{270}$ Furthermore, while the AIFC Courts feature elective jurisdiction, what its staff calls "opt in" jurisdiction, the founders of the AIFC Courts decided not to include conduit jurisdiction. Rather, given the difficult political environment, they sought to minimize potential challenges to the AIFC Courts' legitimacy. The AIFC Courts include mechanisms to both enforce the arbitral awards of the AIFC Arbitration Centre ${ }^{271}$ and to ensure that orders of the AIFC Courts receive the same recognition as onshore courts. ${ }^{272}$ It remains to be seen whether these modifications will steer the AIFC Courts clear of jurisdictional conflicts with the host state.

\section{B. Hong Kong and Singapore}

The transition to Xi Jinping regime and after has been seen to erode the autonomy of the HKSAR. In recent years, there have been a number of signals that the PRC is tightening control over the HKSAR legal system. Examples include the Standing Committee of the NPC's role in the Congo case in $2011^{273}$ and in the oath-taking of two Legislative Council candidates in $2016,{ }^{274}$ as well as the "co-location" train station project that provides an entry for PRC jurisdiction into Hong Kong. ${ }^{275}$ These signs of

\footnotetext{
${ }^{269}$ For example, the Law Academy is developing programs to teach Emirati lawyers common law that provides the lawyer with credit to become a practitioner in the DIFC Courts (currently, most practitioners are from the United Kingdom or United States).

${ }^{270}$ See AIFC Constitutional Statute, Dec. 7, 2015, Art. 13(2), available at http://laws.aifc.kz/storage/files/47ba42d60f3e4766/Unofficial\%20English $\% 20$ translation $\% 20$ of $\% 20$ the $\% 2$ 0Contitutional $\% 20$ Statute $\% 20$ On $\% 20$ the $\% 20$ AIFC $\% 20$ as $\% 20$ amended $\% 20$.pdf.

${ }^{271}$ See id., art. 14(3).

${ }^{272}$ See id., art. 13(8).

${ }^{273}$ See Democratic Republic of the Congo \& Others v. FG Hemisphere Assocs. LLC, [2011] 1 H.K.C. F.A. 41 at [524] (C.F.A.) (deferring to the Standing Committee of the NPC to interpret the Basic Law's standard for sovereign immunity).

${ }^{274}$ See Benjamin Haas, Hong Kong Pro-Democracy Legislators Disqualified from Parliament, THE GUARDIAN (July 14, 2017), https://www.theguardian.com/world/2017/jul/14/hong-kong-pro-democracylegislators-disqualified-parliament (explaining the disqualification of pro-democracy members-elect used the oath-taking ceremonies during inaugural meetings to protest Chinese rule). See also "Interpretation of Article 104 of the Basic Law of the Hong Kong Special Administrative Region of the People's Republic of China by the Standing Committee of the National People's Congress," adopted by the Twelfth National People's Congress at Its Twenty-fourth Session on November 7, 2016 (interpreting article 104 of the Basic Law to prohibit any reading that "takes the oath in a manner which is not sincere or not solemn").

${ }^{275}$ See Hong Kong Legislative Council, Guangzhou-Shenzhen-Hong Kong Express Rail Link (Co-Location Bill), (Jan. 16, 2018), https://www.thb.gov.hk/eng/policy/transport/policy/colocation/[Eng]\%20LegCo\%20Brief\%20on\%20XRL \%20Co-location\%20Bill.pdf (outlining the proposal to set up a high-speed railway between Hong Kong and Guangzhou in mainland China). But see Lok-kei Sum, Legal Experts See Co-Location Challenges, THE STANDARD (Dec. 29, 2017), http://www.thestandard.com.hk/section-news.php?id=191165\&sid=11 (explaining how conferring full jurisdiction to PRC officers over part of the West Kowloon terminal violates the Basic Law).
} 
PRC encroachment in the core institutions of the HKSAR legal system and in its territorial integrity cast doubt on the attractiveness of Hong Kong as a jurisdiction for international commercial disputes. Hong Kong's status as a legal hub may thus be devolving following regime change, from the British colonial government to the PRC Government. Whatever the actual impact on the HKSAR legal system, Beijing's actions are starting to erode the confidence of the international business community in Hong Kong's legal services, moving Hong Kong from a stronger state support type to a weaker one.

One response by the HKSAR Government has been to copy Singapore, which has not suffered the kind of challenges experienced by Hong Kong or the DIFC Courts. Hong Kong announced in early 2017 that it is building a legal hub, strikingly similar to Maxwell Chambers, to be operational by 2019. The Hong Kong Government has allocated space in the West Wing of the former Central Government Offices (renamed "Justice Place") and the heritage-listed French Mission Building, as the designated area for a "legal hub" that features seventeen "law-related organizations," including the CIETAC Hong Kong Arbitration Center, the China Maritime Arbitration Commission Hong Kong Arbitration Center, and the Chinese Arbitration Association of Taipei. ${ }^{276}$ The inclusion of these dispute resolution institutions evinces the integration of the "regional" into the hub, an example of the concentration of specialized service firms as subject to agglomeration economies. ${ }^{277}$ Noteworthy is the HKIAC's decision to opt out of the new legal hub based on its assessment, contrary to cluster theory, that its location conferred upon it a competitive advantage. ${ }^{278}$ Nonetheless, Hong Kong's "legal hub" is seen to advance Hong Kong's dispute resolution services. Maxwell Chambers has countered with "Maxwell Chambers Suites," a 3500-square meter acquisition of the neighboring building, also a conservation site, at a cost of S\$25 million (US\$18.1 million). ${ }^{279}$

The construction of the physical "legal hub" in Hong Kong shows how discourses can be transformed into concrete venues, or how organic hubs can be made more artificial. In the case of Hong Kong, the subnational government is able to pursue its selfinterest; that is to say, the PRC has not completely dominated the HKSAR Government. The Hong Kong "legal hub" could, in fact, be in Beijing's favor, pursuant to the BRI. The skeptical view is that the PRC Government is so focused on turning the political will of Hong Kong toward Beijing that it will subjugate Hong Kong's commercial well-being for this purpose.

\section{Shanghai and Shenzhen}

Given the long history of inter-provincial rivalry in China, it is not surprising that NLHs in Shanghai and Shenzhen have triggered competition in other municipalities, an effect that could be either positive or negative. Some of the sources of this competition are more serious than others. Xi'an, which has positioned itself as the terminus point for the overland "belt" portion of the BRI, is building a legal hub. Its hub is centered on one

\footnotetext{
${ }^{276}$ Interview, HKDOJ, Hong Kong, Mar. 27, 2018.

277 Saskia Sassen, The Global City: Introducing a Concept, 11 Brown J. World AFF. 29 (2005).

${ }^{278}$ Site visit to Maxwell Chambers, Aug. 13, 2018. See also Global Arbitration Review, Guide to Regional Arbitration (volume 6-2018) Survey Results (Nov. 17, 2017),

https:/globalarbitrationreview.com/insight/guide-to-regional-arbitration-volume-6-2018/1150108/surveyresults (naming the HKIAC as world leader in terms of its location).

${ }^{279}$ Interview with Ministry of Law, Aug. 16, 2018.
} 
of China's two international commercial courts (the other being located in Shenzhen), housed in the same building as the "no. 6 circuit court." Officials there want to build the city's capacity to administer international commercial dispute resolution pursuant to the BRI. ${ }^{280}$ However, Xi' an suffers from low levels of legal infrastructure, legal services, and legal culture, and as a result, faces a steep climb. A more likely contender is Hangzhou, which has also entered the hub race. Hangzhou enjoys greater infrastructural support, aggregation, and internationalization in its legal services. Alibaba, which is based in Hangzhou, has established both private and public "Internet courts" which have the potential to radically alter some of the geographic preconditions of hubs (i.e., the Internet courts have jurisdiction on Internet-related commercial disputes throughout the PRC, although disputes are, to date, primarily domestic). ${ }^{281}$ The Hangzhou International Arbitration Court has also started to internationalize, as evinced by an MOU with the DIFC Courts. ${ }^{282}$ Given its centrality to e-commerce, Hangzhou may pave the way for a new kind of NLH, one that is more digital than territorial.

The most serious challenge to Shanghai and Shenzhen as hubs has come in the form of pushback from CIETAC's Secretariat in Beijing. The financial success of the CIETAC subcommissions in Shanghai and Shenzhen had piqued the attention of Beijing. On May 1, 2012, the CIETAC Arbitration Rules came into force that had the practical effect of strengthening the CIETAC Secretariat's position as default venue for arbitrations that failed to specify a subcommission. ${ }^{283}$ The following day, the subcommissions announced their independence from CIETAC, changed their names to SHIAC and SCIA, and issued their own rules and panels of arbitrators. The CIETAC Secretariat disputed these newly established institutions and re-established its own subcommissions. Thereupon, for several years, parties encountered uncertainty in determining which arbitral institution had jurisdiction until the SPC intervened by issuing a "reply" (huifu) in 2015, confirming the independence of CIETAC, SHIAC, and SCIA. ${ }^{284}$ The CIETAC "civil war" as arbitrators refer to it, illustrates how hubs can be the victims of their own success, incurring greater control by the political center. However, in this instance, the hubs appear to have protected their autonomy, demonstrating that in some artificial hubs, it is possible for power-sharing to exist alongside top-down directives.

The independent variable of state support influences the viability of the NLH, support that can paradoxically constrain hubs if their dispute resolution mechanisms are

\footnotetext{
${ }^{280}$ Interview, Singapore, Aug. 15, 2018.

${ }^{281}$ Dani Deahl, China Launches Cyber-Court to Handle Internet-Related Disputes, The Verge (Aug. 18, 2017), https://www.theverge.com/tech/2017/8/18/16167836/china-cyber-court-hangzhou-internet-disputes; Jim Erickson, How Taobao is Crowdsourcing Justice in Online Shopping Disputes, AzILA (July 17, 2014), https://www.alizila.com/how-taobao-is-crowdsourcing-justice-in-online-shopping-disputes/.

${ }^{282}$ Memorandum of Understanding for the Furtherance of Collaboration between the Hangzhou Arbitration Commission and the Dubai International Financial Centre's Dispute Resolution Authority, signed Oct. 27, 2017.

${ }^{283}$ CIETAC Arbitration Rules (May 1, 2012), available at http://www.cietachk.org/cms/fileDownloadServlet/attachmentDownload?contentID=11691.

${ }^{284}$ See Supreme People's Court, Zuigao renmin fayuan guanyu dui Shanghai shi gaoji renmin fayuan deng jiusheji Zhongguo guoji jingji maoyi zhongcai weiyuanhui jiqi yuanfenhui deng zhongcai jigou suo zuo zhongcai caijue sifa shencha anjian qingshi wenti de pifu (最高人民法院关于对上海市高级人民法院等 就涉及中国国际经济贸易仲裁委员会及其原分会等仲裁机构所作仲裁裁决司法审查案件请示问题的 批复) (July 17, 2015), http://www.court.gov.cn/zixun-xiangqing-15003.html.
} 
not sufficiently independent from the host state. Due to such factors as regime change and onshore institutional pushback, Hong Kong, Dubai, Shanghai, and Shenzhen have each, to varying degrees, undergone limitations on their capacity to accept commercial disputes. The drivers of these limitations are intrastate politics more than deglobalization. Deglobalization, the extent to which it continues and deepens, may exacerbate existing tensions. The U.S.-China trade war, for instance, could result in a slowdown in the manufacturing sector in China, which may hurt not just China but also dependent economies in Hong Kong and Singapore. It is reasonable to assert that the growth of Inter-Asian hubs is pegged to China's continued global trade and outbound direct investment. Ultimately, China must develop independent dispute resolution mechanisms in order for its hubs to be commercially viable, a prospect that seems uncertain given existing structural constraints (i.e., the dominance of the Chinese Communist Party).

\section{Interhub Ordering}

NLHs exist by creating platforms for multinational corporations to resolve their disputes in accordance with transnational law. They do so through optimizing conflict of law rules for parties; and their responses to the challenges of host state pushback similarly demonstrate their ongoing reforms. These optimizations can be summarized as (1) evolving jurisdictions, (2) enhanced enforcement, and, to a lesser extent, (3) the business of choice of law. Jurisdictions evolve as a result of both endogenous and exogenous pressures. The former is exemplified by the expansive jurisdiction of the DIFC Courts and its efforts to maximize the number of potential parties to dispute. Exogenous pressures include pushback from the state, as in the form of onshore courts in Dubai or the PRC that is constraining Hong Kong's autonomy. Second, NLHs show enhanced enforcement through intrahub and interhub connections. Intrahub connections refer to the cross-institutional links, for instance, the DIFC Court's mechanism to convert judgments into arbitral awards. Likewise, Singapore's arb-med-arb is yet another method to increase the likelihood of enforcement. Alternately, dispute resolution may be collapsed into one mechanism such as SCIA's 2016 efforts to accept investor-state cases - the first such attempt in China. ${ }^{285}$ Interhub connections are those such as soft law that signals intent to recognize and enforce court judgments. A third lesser factor in NLH's optimization of conflict of law rules is their demonstrating how the business of choice of law works, moving the analysis of choice of law upstream to show how dispute resolution institutions influence parties' choice of law. So rather than the question of "who decides," hubs also try to address the question "who's law" by promoting their own law for parties' contracts. For instance, not just Hong Kong and Singapore's but also Dubai and Astana's "pro-business" law, as the promotions go, provides the certainty of common law decisions. Promoting one's own law further benefits legal services providers who are members of the local bar and experts in the domestic law. In practice, NLHs' promotion of choice of substantive law in many cases overrides exclusive use of local law. Hence, NLHs compete on the quality of their legal services and procedural efficiency, rather than, necessarily, supplying the law itself. In summary, NLHs are crucibles of procedural, technological, and doctrinal innovation. Much of this innovation

${ }^{285}$ See Shenzhen Court of International Arbitration, supra note 254, art. 2(2). 
is driven by nondemocratic or hybrid states' need to establish their legitimacy for international business (in the case of artificial hubs) or leverage transnational legal services for economic gain (as in organic hubs).

Many of these innovations, however, are ineffective or even unlawful. The DIFC Courts' mechanism to convert judgments into arbitral awards is unused and potentially violates the spirit of the New York Convention. Likewise, arb-med-arb nullifies some of the voluntariness of mediation and requires both parties to sign on to arbitration. Hubs in Dubai and Singapore are not alone in over-reaching their mandates. In Shenzhen, the 2016 SCIA rules violate the Arbitration Law of the PRC that allows only for commercial arbitration. ${ }^{286}$ These examples suggest that the public relations functions of hubs, to some extent, override practical considerations. ${ }^{287}$ This is not to dismiss para-ethnographic theories of hub proponents but to draw attention to the fact that not only are hubs laboratories of experimentation, but "buzz" serves instrumental means, signaling the aim of nondemocratic states to enter the international dispute resolution market. Not all artificial hubs may thrive, but they are first attempts to stake a claim in the lucrative and prestigious industry of international commercial dispute resolution.

There are three implications of this overreach: the first is the dispute resolution question (whether NLHs really overcome host state challenges); the second is a theoretical question (whether the exception can serve as the basis of order); and the third is the China question (whether the presence of Chinese NLHs affects the decentralized network).

\section{A. The Dispute Resolution Question}

On the one hand, it is clear that several hubs have lost some status as a result of movements in their own jurisdiction or that of the larger host state, and are pushing back against movements that undercut their work. On the other hand, hubs' responses may further entrench the elite quality of legal globalization exacerbating deglobalization blowback. For instance, in advance of Brexit, the City, as the original hub, established the Standing International Forum of Commercial Courts (SIFoCC) in 2017, a unique forum of thirty-seven commercial courts from twenty-eight countries, including four courts from Europe. ${ }^{288}$ SIFoCC is currently working on a multilateral MOU for the courts, which would be a public document that would improve the accessibility of the law and encourage parties to adopt a choice of courts clause and provide guidance on the procedures for recognizing and enforcing each other's judgments. ${ }^{289}$ Such an MOU may provide some comfort to post-Brexit U.K. courts that their judgments will be recognized by at least the four European member states' courts, given that the Recast Brussels Regulation $(2015)^{290}$ have yet to be renegotiated. SIFoCC is a "self-conscious

\footnotetext{
${ }^{286}$ See Arbitration Law of the PRC, adopted by the Ninth Meeting of the Standing Committee of the Eighth NPC on Oct. 31, 1994, article 2.

${ }^{287}$ For instance, the 2016 SCIA rules violate the Arbitration Law of the PRC, adopted by the Ninth Meeting of the Standing Committee of the Eighth NPC on Oct. 31, 1994, article 2 that allows only for commercial arbitration.

${ }^{288}$ The Standing International Forum of Commercial Courts (Oct. 18, 2018), https://www.sifocc.org/countries/.

${ }^{289}$ Interviews at the second meeting of SIFoCC, New York, Sept. 28, 2018.

${ }^{290}$ See Regulation (EU) No. 1215/2012.
} 
construction of a global judicial community" 291 that overlaps with the ongoing deliberations over a Hague Convention on the Recognition and Enforcement of Foreign Judgments (hereinafter "Hague Convention"). ${ }^{292}$ The issue is that SIFoCC is a small ultra-elite club, and from the deglobalist's point of view, it is unclear that SIFoCC is going to address the legal needs of those who feel left behind. The hierarchical monetary sovereignty ${ }^{293}$ of NLHs does not lend themselves to "flat rules," namely, accessibility to ordinary people. ${ }^{294}$

\section{B. The Theoretical Question}

Whether exceptional zones like NLHs can serve as the basis of orders, from the state's perspective, NLHs are jurisdictional carve-outs, but from the view of the international political economy, NLHs as with other types of exceptional zones, are increasingly the norm. International business and private ordering often go hand in hand, as Dezalay and Garth, pointed out over two decades ago. ${ }^{295}$ NLHs include international commercial arbitration - the focus of Dezalay and Garth's study — which produces its "own form of private justice." ${ }^{, 296}$ Further, a common past rooted in the British Empire and the dual logics of competition and collaboration give rise to some degree of uniformity in the substantive law governing contract disputes as well as the procedures for dispute resolution. This uniformity is not one only of Inter-Asia (located primarily in the "global South") but also forms ties with the North, through such networks as SIFoCC and interhub connections between, say, the DIFC Courts and New South Wales. ${ }^{297}$ Thus, hubs offer some measure of "normative settlement," one requirement for transnational legal orders. ${ }^{298}$ Yet, hubs are more than their constitutive parts, and whereas international commercial arbitration may produce order, NLHs, as aggregations of dispute resolution may not necessarily produce aggregations of order. The connective tissue within and between hubs, their cross-institutional mechanisms and the soft law, may be unreliable. Thus, while there were design attempts to produce order, because of the over-sell of NLHs' innovations, the effects may be less than desirable.

\section{The China Question}

China may be the jurisdiction that will witness the largest growth in NLHs in the near term. China already has the cultural capital to build hubs; it is not surprising that ideas that are either central to or derive from exceptional zones, such as Sander's "onestop shop" or Nobel Prize-winning economist Paul Romer's “charter cities," were

\footnotetext{
291 Anne-Marie Slaughter, A Global Community of Courts, 44 HARV. INT'L L.J. 191, 196 (2003).

${ }^{292}$ See Special Commission on the Recognition and Enforcement of Foreign Judgments of the Hague Conference on Private International Law, 2018 Draft Convention, May 24-29, 2018 (on file with the author). A participant in the Special Commission attended the second meeting of SIFoCC in New York City on September 27, 2018 to discuss the work of the Hague Conference and to encourage the justices to engage in "judicial lobbying" with their home states to sign on to the Hague Convention. Interview with participant in the Hague Conference, New York City, Oct. 15, 2018.

${ }^{293}$ See Pistor, supra note 84.

${ }^{294}$ See HADFIELD, supra note 107, at 307.

295 See supra Dezalay and Garth note 32.

${ }^{296} \mathrm{Id}$. at 316.

${ }^{297}$ See supra note 217.

298 Terence C. Halliday \& Gregory Shaffer, Introduction: Transnational Legal Orders, in TRANSNATIONAL LEGAL ORDERS 3, 43-5 (Terence C. Halliday \& Gregory Shaffer eds., 2015).
} 
inspired by China. ${ }^{299}$ Further, China has the will to build hubs; in 2017, after a lecture in Hangzhou on NLHs, representatives of the local judiciary and arbitration commission both asked me, "Legal hubs? How do we build one of those?" It is true that China is offshoring law, or more precisely, onshoring offshore law. There are efforts to bring transnational law to the PRC jurisdiction so that foreign parties must adjudicate, arbitrate, or mediate within the PRC. The new international commercial courts and the financial court in Shanghai are domestic Chinese versions of parallel institutions elsewhere. China is not only building its own hubs but also starting to create its own SIFoCC-like interhub networks. ${ }^{300}$ Most likely, in the near term, Chinese versions of hubs and their networks do not necessarily altar the decentralized system of hubs, nor do they oppose the basis of the international economic order that underlies it.

\section{Conclusion}

NLHs are an emergent feature of the international commercial dispute resolution landscape, which facilitate cross-border transactions by anchoring transnational law through optimization of conflict of laws rules at the local level. The success of NLHs depends on host state support, and yet such support can potentially constrain independent legal institutions. Certain NLHs, those that are more or less "organic," such as Hong Kong and Singapore, have achieved success in attracting international disputes and, accordingly, channeling capital flows and exporting their services. Both hubs have strong reputations for international arbitration, yet the reputations of their courts are diverging due to political pressure. Whereas in Singapore, courts have been able to maintain their reputation for fairly adjudicating commercial matters; the same cannot be said for Hong Kong where political pressure from Beijing has led to the perception that its courts are losing their neutrality even in commercial matters. Whereas, to date, there is little evidence of such backsliding, nonetheless, in the hyper-competitive field of NLHs, perception matters.

Among the "artificial" NLHs, the DIFC Courts has developed a strong reputation for professionalism. It is too soon to say whether the Joint Tribunal will sufficiently redefine the DIFC Courts' jurisdiction to curtail its international operations. Similarly, Astana, Shanghai, and Shenzhen are too new to conclude whether they will succeed or fail. Nonetheless, each faces the challenge of surmounting the dual challenge of overcoming the public relations deficit of its host state while maintaining independence from the host state, a challenge that abides despite much of the branding of Inter-Asia by the BRI.

In terms of positive spillover effects, most hubs appear self-contained and do not yet appear to stimulate innovation outside of the hub. One partial exception is the inter-

\footnotetext{
299 "Leading the Alternative Dispute Resolution (ADR) Field," http://franksander.com/leading-thealternative-dispute-resolution-field/ (last visited Oct. 22, 2018) (explaining how Sander was inspired by China); Paul Romer, Interview on Urbanization, Charter Cities and Growth Theory, PAULROMER.NET (June 8, 2018), https://paulromer.net/tag/charter-cities/ (link broken) (mentioning how Romer was inspired by Deng Xiaoping's policies).

${ }^{300}$ See e.g., Joint Statement of the World Enforcement Conference (drafted by the Supreme People's Court following a high-level conference in Shanghai on January 20-23, 2019, featuring presidents and chief justices of supreme courts).
} 
provincial and inter-regional competition of China, which incentivizes competition. Hong Kong has created positive spillover across the border into Shenzhen, and Shenzhen and Shanghai are, in turn, producing imitations in other provinces, many of which are prestige projects and will fail. Positive spillover does not need to take the form of duplication; instead, it could lead to more targeted reform in the dispute resolution counterparts of poorer provinces, including judicial and arbitral training. To date, there has been very little of such effects.

On the question of the aggregate impact of interhubs ordering, NLHs are nexuses for multiple and overlapping legal orders. Some of these are rooted in older global orders like empire, but most are a result of economic globalization. NLHs' capacity to combine corporate-driven transnational law with flexible conflict of law rules is central to their work. Yet because many of the intrahub procedural innovations and interhub soft law ties are of questionable utility in practical terms, NLHs are tenuous. Hubs are most vulnerable where they are meant to be most inventive, specifically, in terms of the enforcement of their courts' judgments beyond the hub. There are thus limits internal to transnational law. Nonetheless, NLHs are growing. This article has established the conceptual groundwork for the study of NLHs. Further work needs to be done on the nature of their specific configurations of transnational law, the parties that use hubs or hub shop, and their broader effects on host states, capital-important states, and capital-exporting states. 


\section{Figure and Tables}

Figure. Spectrum of legal hubs.

\begin{tabular}{|c|c|c|}
\hline \multirow{2}{*}{$\begin{array}{l}\text { Top tier } \\
\text { Lower tier }\end{array}$} & Hong Kong & \\
\hline & & Shanghai Shenzhen DIFC AIFC \\
\hline & Organic & Artificial \\
\hline \multirow{4}{*}{ Attributes } & Evolve over longer period of time & Evolve over shorter period of time \\
\hline & More mature legal services & Less mature legal services \\
\hline & Supply-driven & Demand-driven \\
\hline & More integrated into former British Empire & Less integrated into former British Empire \\
\hline
\end{tabular}

Table 1. HKIAC Caseload for BRI deals.

\begin{tabular}{|l|l|l|l|l|l|}
\hline & $\mathbf{2 0 1 4}$ & $\mathbf{2 0 1 5}$ & $\mathbf{2 0 1 6}$ & $\mathbf{2 0 1 7}$ & Total \\
\hline $\begin{array}{l}\text { No. of Arbitrations Involving Parties from BRI Countries Under } \\
\text { 2013 HKIAC Rules }\end{array}$ & 94 & 74 & 70 & 124 & 362 \\
\hline $\begin{array}{l}\text { No. of Arbitrations Between a PRC Party and a Party from } \\
\text { Another BRI Country Under 2013 HKIAC Rules }\end{array}$ & 12 & 10 & 12 & 38 & 72 \\
\hline
\end{tabular}

Table 2. HKIAC Caseload for PRC parties.

\begin{tabular}{|l|l|l|}
\hline Year & $\begin{array}{l}\text { No. Arbitration } \\
\text { Matters Involving } \\
\text { PRC Parties }\end{array}$ & $\begin{array}{l}\text { \% of Overall Arbitration } \\
\text { Matters }\end{array}$ \\
\hline 2017 & 103 & $34.7 \%$ \\
\hline 2016 & 58 & $22.1 \%$ \\
\hline 2015 & 135 & $49.8 \%$ \\
\hline 2014 & 102 & $40.5 \%$ \\
\hline
\end{tabular}


Table 3. Legal hubs' statistics (2017).

\begin{tabular}{|l|l|l|l|l|l|l|}
\hline Hub & $\begin{array}{l}\text { No. } \\
\text { Lawyers } \\
\text { (incl. } \\
\text { domestic } \\
\text { and } \\
\text { foreign) }\end{array}$ & $\begin{array}{l}\text { No. Law } \\
\text { Firms } \\
\text { (incl. } \\
\text { domestic } \\
\text { and } \\
\text { foreign) }\end{array}$ & $\begin{array}{l}\text { No. } \\
\text { International } \\
\text { Arbitration } \\
\text { Centersł }\end{array}$ & $\begin{array}{l}\text { No. New } \\
\text { Cases Filed } \\
\text { at Largest } \\
\text { Arbitration } \\
\text { Centre }\end{array}$ & $\begin{array}{l}\text { No. Cases of } \\
\text { International } \\
\text { Commercial } \\
\text { Court }\end{array}$ & $\begin{array}{l}\text { International } \\
\text { Commercial } \\
\text { Court's } \\
\text { Total No. } \\
\text { Cases for } \\
\text { Which Both } \\
\text { Parties Are } \\
\text { Foreign+++ }\end{array}$ \\
\hline $\begin{array}{l}\text { City of } \\
\text { London }\end{array}$ & $29,092^{*}$ & 600 & 3 & 285 & 158 & $59.3 \%$ \\
\hline Hong Kong & $10,896 \dagger$ & $1065^{\text {a }}$ & 5 & $532 *$ & N/A & N/A \\
\hline Singapore & 6550 & $1078^{\text {a }}$ & 4 & 452 & 9 & $72 \%$ \\
\hline Dubai/DIFC & $2300^{\circ}$ & $70^{\circ \circ}$ & 2 & $208^{\Delta \Delta}$ & $24 * * *$ & $37 \%$ \\
\hline $\begin{array}{l}\text { Kazakhstan/ } \\
\text { AIFC }\end{array}$ & - & $32(6)^{\Delta}$ & 1 & $\begin{array}{l}\text { Have not } \\
\text { started } \\
\text { receiving } \\
\text { cases. }\end{array}$ & $\begin{array}{l}\text { Have not } \\
\text { started } \\
\text { receiving } \\
\text { cases. }\end{array}$ & N/A \\
\hline Shanghai & 20,319 & $\begin{array}{l}1463 \\
(4) \dagger \dagger\end{array}$ & 5 & 740 & N/A & N/A \\
\hline Shenzhen & 12,099 & $\begin{array}{l}775 \\
(30)++ \\
(7)^{\text {aa }} \\
(1)^{* *}\end{array}$ & 2 & & $\begin{array}{l}\text { Unavailable. } \\
\text { Have not } \\
\text { started } \\
\text { receiving } \\
\text { cases. }\end{array}$ & N/A \\
\hline
\end{tabular}

* Refers to practicing-holding solicitors (i.e., those licensed to practice in England Wales) and not foreign licensed lawyers.

$\dagger$ Refers to 9463 Hong Kong lawyers and 1433 registered foreign lawyers.

- Refers to licensed advocates (UAE nationals) and legal consultants (foreigners).

+ Refers to registered practitioners in the DIFC from the DIFC, Dubai, UAE, and abroad.

${ }^{a}$ Includes solicitor advocates.

$\circ$ This number is from 2014.

${ }^{\Delta}$ Refers to firms registered with the AIFC.

$\dagger \dagger$ Refers to the number of foreign law firms registered in the Zone.

++ Refers to the number of PRC law firms in the District.

${ }^{a a}$ Refers to the number of "joint ventures" between PRC and Hong Kong law firms in the District.

** Refers to number of foreign law firms in the District.

$\ddagger$ Refers to full service venues and branches of arbitration houses elsewhere.

- Includes 297 arbitrations, 15 mediations, and 220 domain name disputes.

${ }^{\Delta \Delta}$ Refers to statistics of the Dubai International Arbitration Centre, including the following categories: arbitration, conciliation, adjudication and appointing authority. The DIFC-LCIA caseload for arbitration specifically was 58 .

*** Refers to judgments in both the Court of First Instance and the Court of Appeals; does not include orders.

+++ Includes companies incorporated outside of the hub jurisdiction that may have established a subsidiary or other presence within the hub. 